\section{Pacific Northwest}

National Laboratory

Operated by Battelle for the

U.S. Department of Energy

\title{
Isotope production at the Hanford Site in Richland, Washington
}

June 1999

Prepared for the U.S. Department of Energy under Contract DE-AC06-76RL01830 


\title{
DISCLAIMER
}

This report was prepared as an account of work sponsored by an agency of the United States Government. Neither the United States Government nor any agency thereof, nor Battelle Memorial Institute, nor any of their employees, makes any warranty, express or implied, or assumes any legal liability or responsibility for the accuracy, completeness, or usefulness of any information, apparatus, product, or process disclosed, or represents that its use would not infringe privately owned rights. Reference herein to any specific commercial product, process, or service by trade name, trademark, manufacturer, or otherwise does not necessarily constitute or imply its endorsement, recommendation, or favoring by the United States Government or any agency thereof, or Battelle Memorial Institute. The views and opinions of authors expressed herein do not necessarily state or reflect those of the United States Government or any agency thereof.

\author{
PACIFIC NORTHWEST NATIONAL LABORATORY \\ operated by \\ BATTELLE \\ for the \\ UNITED STATES DEPARTMENT OF ENERGY \\ under Contract DE-AC06-76RLO 1830
}

Printed in the United States of America

Available to DOE and DOE contractors from the

Office of Scientific and Technical Information, P.O. Box 62, Oak Ridge, TN 37831;

prices available from (615) $576-8401$.

Available to the public from the National Technical Information Service, U.S. Department of Commerce, 5285 Port Royal Rd., Springfield, VA 22161 


\section{Isotope Production at the Hanford Site in Richland, Washington}

June 1999

Information provided to the Nuclear Energy Research Advisory Committee's subcommittee on the development of a 'Long-Term Isotope Research and Production Plan"

Prepared by the Hanford Radioisotopes Program staff at the Pacific Northwest National Laboratory

Richland, Washington 99352 


\section{Contents}

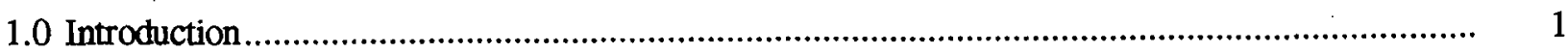

2.0 Radioisotope Production at the Hanford Site ....................................................................

2.1 History of Isotope Production Activities at the Hanford Site ............................................

2.2 Current Program Activities Sponsored by the Department of Energy .................................. 2

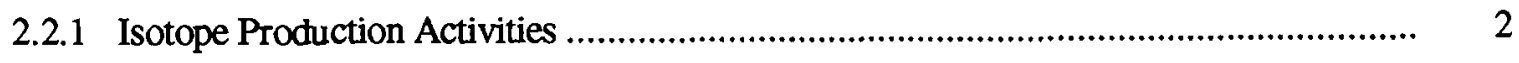

2.2.2 Commercialization and Leasing/Licensing of Isotope Products ................................ 3

2.3 Future Plans for Isotope Production at the Hanford Fast Flux Test Facility .........................

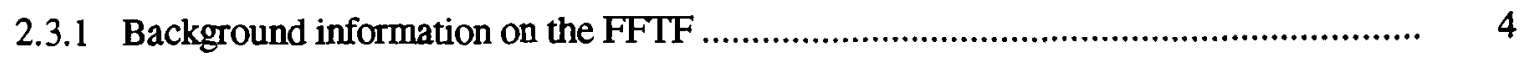

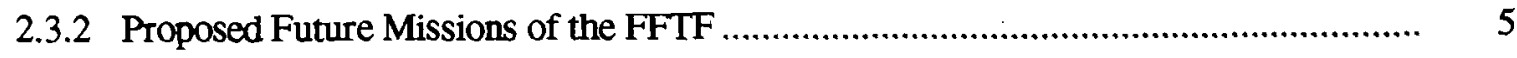

2.3.3 Capability of the FFTF for Isotope Production .....................................................

2.3.4 Candidate Medical Isotopes to be Produced at FFTF and Comparison with Market Demand and Other DOE Reactor Capabilities............................................... 8

2.4 Organizational Structure of the Radioisotopes Production Program ................................... 17

2.4.1 Pacific Northwest National Laboratory's Radiochemical Processing Group ............... 17

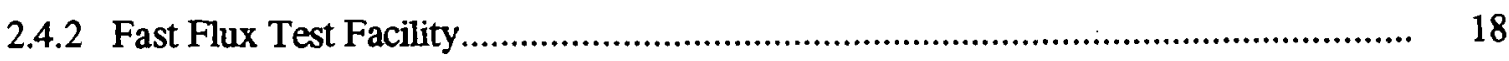

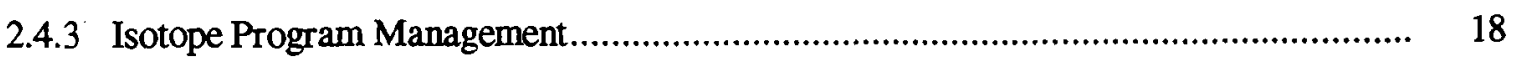

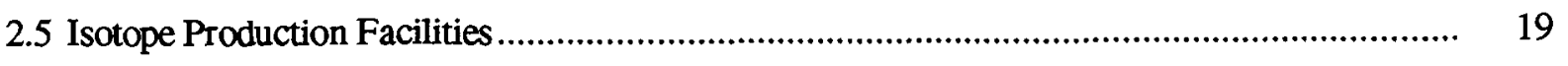

2.5.1 Radiochemical Processing Laboratory ................................................................ 19

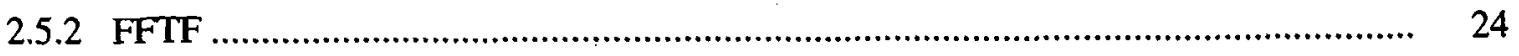

2.5.3 Other Facilities Relevant to the Proposed Future FFTF Isotope Production Mission............................................................................................ 29

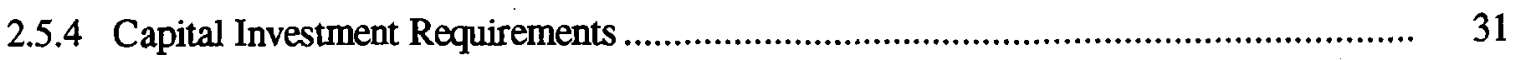


2.6 Isotope Production Costs, Pricing, and Sales Record..

2.6.1 Activity-Based Costing and Isotope Pricing ........................................................ 32

2.6.2 Isotope Sales and Customer Service Record ........................................................... 36 


\section{Figures}

1 Annual Sales of Yttrium-90 Produced at the Hanford Site Since FY 1991 ................................. 3

2 (A) Hydrided Test Assembly Used in a 1987 FFTF Experiment to Produce Gadolinium-153 and Cobalt-60

3 Comparison of FFTF Neutron Spectra With and Without Yttrium Hydride Moderator Pins .........

4 Neutron Energy Requirements for Optimum Production of Reactor-Generated Medical Isotopes

5 Organizational Chart for the PNNL Environmental Technology Division....

6 Organizational Chart for the Fast Flux Test Facility

7 Map of the First Floor of the Radiochemical Processing Laboratory, Showing Occupied and Vacant Chemistry Laboratories

8 Map of the Basement of the Radiochemical Processing Laboratory, Showing Occupied and Vacant Chemistry Laboratories

9 Proposed Locations on the First Floor of the Radiochemical Processing Laboratory

10 Proposed Locations in the Basement of the Radiochemical Processing Laboratory for Assembly, Processing, and Storage of FFTF Targets

11 Fast Flux Test Facility Reactor Containment Building and External Support Facilities.

12 FFTF Plant Arrangement

13 Schematic of FFTF Main Heat Transport System (MHTS) .................................................. 26

14 Cutaway View of the FFTF Reactor Containment Building ................................................ 26

15 Closed Loop Ex-Vessel Machine (CLEM) for Installing Target Assemblies at FFTF .................. 27

16 Interim Examination and Maintenance (IEM) Cell Used to Remove Residual Sodium ................. 28

17 First Floor Plan for Building 306E, Showing Locations for FFTF Target Preparation and Nondestructive Testing..

18 Floor Plan of the Postirradiation Testing Laboratory (PTL). 
19 Floor Plan of the FFTF Maintenance and Storage Facility (MASF)

20 Flowchart Representing Procedures in the Packaging and Shipping of Vials of Yttrium-90 from PNNL to Medical Customers. 


\section{Tables}

1 Thirty Candidate Medical Isotopes for Production at FFTF ................................................

2 FFTF Production Advantages for Medical Isotopes ................................................................ 12

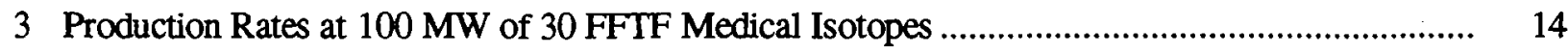

4 FFTF Medical Isotope Production versus U.S. Demand........................................................... 15

5 Comparison of Medical Isotope Production at FFTF and HFIR .......................................... 16

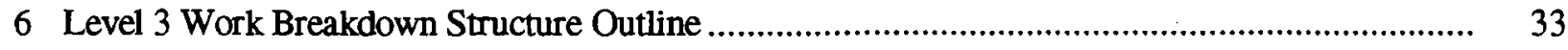

7 Yttrium-90 Packaging and Shipping Cost Analysis......................................................

8 Yttrium-90 Customer Service Record............................................................................. 


\subsection{Introduction}

This report was prepared in response to a request from the Nuclear Energy Research Advisory Committee (NERAC) subcommittee on "Long-Term Isotope Research and Production Plans." The NERAC subcommittee has asked for a reply to a number of questions regarding (1) "How well does the Department of Energy (DOE) infrastructure serve the need for commercial and medical isotopes?" and (2) "What should be the long-term role of the federal government in providing commercial and medical isotopes?"

Our report addresses the questions raised by the NERAC subcommittee, and especially the 10 issues that were raised under the first of the above questions (see Appendix). These issues are related to the isotope products offered by the DOE Isotope Production Sites, the capabilities and condition of the facilities used to produce these products, the management of the isotope production programs at DOE laboratories, and the customer service record of the DOE Isotope Production Sites.

An important component of our report is a description of the Fast Flux Test Facility (FFTF) reactor at the Hanford Site and the future plans for its utilization as a source of radioisotopes needed by nuclear medicine physicians, by researchers, and by customers in the commercial sector.

In response to the second question raised by the NERAC subcommittee, it is our firm belief that the supply of isotopes provided by DOE for medical, industrial, and research applications must be strengthened in the near future. Many of the radioisotopes currently used for medical diagnosis and therapy of cancer and other diseases are imported from Canada, Europe, and Asia. This situation places the control of isotope availability, quality, and pricing in the hands of non-U.S. suppliers. It is our opinion that the needs of the U.S. customers for isotopes and isotope products are not being adequately served, and that the DOE infrastructure and facilities devoted to the supply of these products must be improved. This perception forms one of the fundamental bases for our proposal that the FFTF, which is currently in a standby condition, be reactivated to supply nuclear services and products such as radioisotopes needed by the U.S. medical, industrial, and research communities.

\subsection{Radioisotope Production at the Hanford Site}

\subsection{History of Isotope Production Activities at the Hanford Site}

The Hanford Site, under management of the Westinghouse Hanford Company (WHC), began isotope production at the FFTF in the 1980s. More than 40 radioisotopes of interest to medical and commercial clients were produced. In many cases, only trace quantities of isotopes, suitable for research applications, were produced. However, several isotopes, such as gadolinium-153 and cadmium-109, were produced in larger quantities and sold for medical applications. All of the radiochemical processing of isotope targets irradiated at FFTF was performed in the radiochemistry laboratories of the Pacific Northwest National Laboratory (PNNL). In 1991, at the request of DOE, the Hanford Site began weekly production of 
yttrium-90, which was in the early stages of clinical testing for the treatment of Hodgkin's lymphoma using a radiolabeled antibody method. PNNL scientists developed a process that was patented in 1996 for the production of ultrapure yttrium-90 from strontium-90 that was retrieved from nuclear waste stockpiles at Hanford (U.S. patent no. 5,512,256, awarded April 30, 1996).

In 1996 WHC transferred the management of the DOE-supported radioisotopes program to PNNL. Under PNNL the program was expanded to include research on the production and applications for cancer therapy of alpha-emitting isotopes such as radium-223 and actinium-225 and the bismuth-213 isotope obtained by decay of actinium-225. In addition, through active marketing conducted in collaboration with DOE-HQ staff, the medical use of yttrium-90 and worldwide sales of this isotope have rapidly increased during the past three years. In part because of its successful management of the medical isotopes program at the Hanford Site, PNNL was requested by the Secretary of Energy in May 1999 to lead the development of a scoping plan for the future missions of the FFTF, an important component of which is the production of radioisotopes to fill the needs of medical and commercial users.

\subsection{Current Program Activities Sponsored by the Department of Energy}

\subsubsection{Isotope Production Activities}

The primary medical isotope produced and sold by PNNL under the sponsorship of the DOE Office of Nuclear Energy, Science and Technology's Isotope Programs Office (DOE/NE-70) has been yttrium-90. Largely because of successful clinical trials in the U.S. and Europe and the consistent weekly supply of high-purity yttrium-90 supplied by PNNL, the sales of this isotope increased rapidly from FY 1996 to FY 1998. The 14-fold increase in sales of this isotope over a two-year period is illustrated in Figure 1.

The rapid increase in yttrium-90 sales led to a successful effort to commercialize the production, marketing, sales, and distribution of this isotope product during the past year (described in Section 2.2.2).

A second area in which research and development activities have been focused during the past three years is the development of efficient separation chemistries for alpha emitters of interest in cancer therapy. The following specific noteworthy accomplishments in alpha-emitter research have been supported primarily by $\mathrm{DOE} / \mathrm{NE}-70$ :

1. new processes for separating and purifying thorium-229, actinium-225, and radium-223 from a mixture of radionuclides were developed, and a U.S. patent was awarded in September 1998 (No. 5,809,394)

2. a new and highly efficient anion exchange procedure was developed to isolate bismuth-213 from its actinium-225 parent, and a U.S. patent was awarded in May 1998 (No. 5,749,042)

3. an automated, computer-controlled generator technique was developed at PNNL, and subsequently demonstrated to achieve an efficient separation of bismuth-213 while allowing complete recovery of the actinium-225 parent species; a U.S. patent application for this technology was filed in 1998 


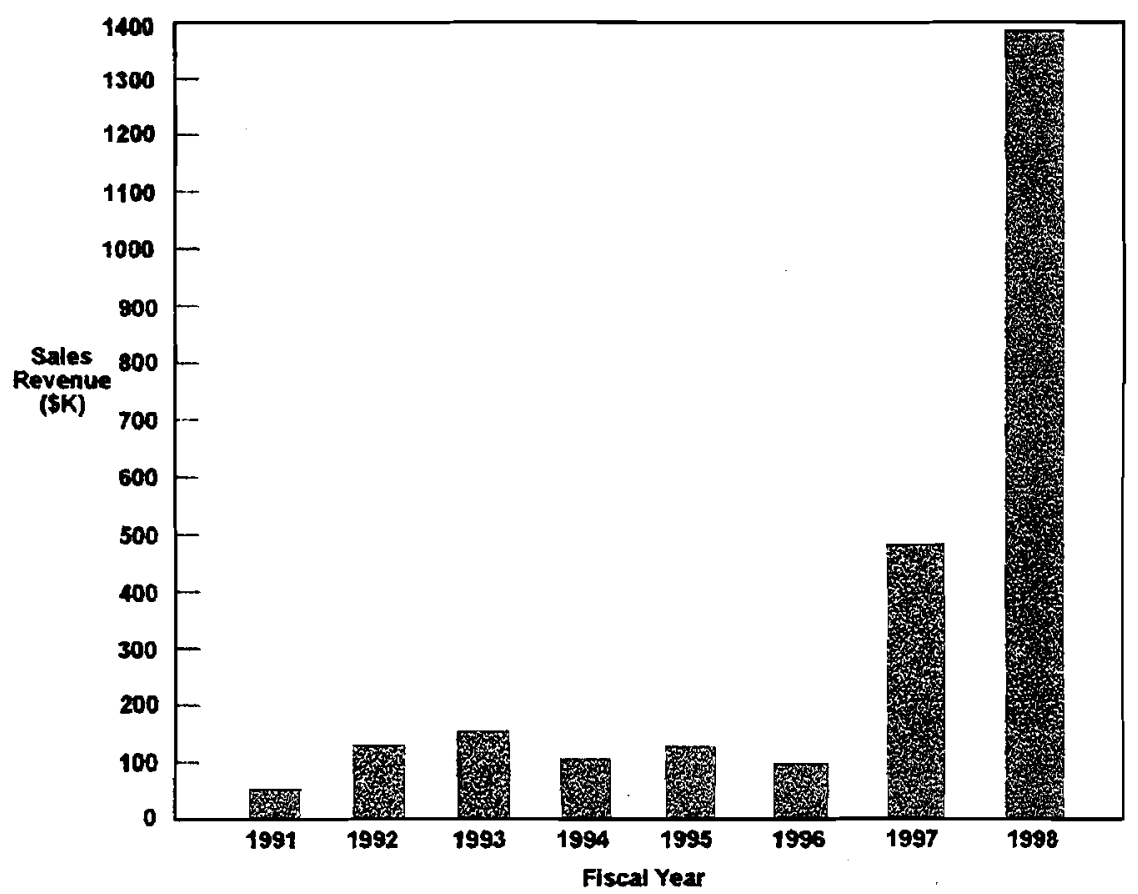

Figure 1. Annual Sales of Yttrium-90 Produced at the Hanford Site Since FY 1991

4. advances were made in developing chelation and linker chemistry for actinium-225 and radium-223 in collaborative work with scientists from the University of Idaho and the University of Washington; two U.S. patent applications were filed in 1998 for new chelating agents of the calixarene and crown ether families that selectively bind actinium-225 and radium-223. [This work was initiated with support from Laboratory-Directed Research and Development (LDRD) funds, and subsequently funded by DOE/NE-70.]

Other research activities with radioisotope products have focused on developing methods for delivering isotopes and radiopharmaceutical products to disease sites. An example of ongoing research supported by the DOE Office of Biological and Environmental Research involves the use of a radioactive polymer composite for administering high-dose brachytherapy to tumors of the prostate gland and other tissues. In this procedure, a direct injection into the tumor mass is made of an isotope solution contained in a polymer material that is a fluid at room temperature, but quickly gels at body temperature and retains the isotope within the tumor region. A U.S. patent application on this procedure was filed in 1998.

With the completion of commercialization of the yttrium-90 production program, PNNL will not continue to serve as a DOE/NE-70 isotope production site in FY 2000. However, special projects related to retrieval of medical isotopes such as thorium- 228 from stored nuclear stockpiles will be carried out on request.

\subsubsection{Commercialization and Leasing/Licensing of Isotope Products}

During FY 1998, a Request for Proposal (RFP) was issued by DOE to commercialize the production, marketing, sales, and distribution of yttrium-90. The proposals submitted were evaluated by a joint 
DOE/PNNL team to select a short list of companies whose proposals were considered acceptable. Negotiations began in mid-1998, and on October 22, 1998, an agreement to lease 40 curies of highly purified strontium-90 for a period of five years was signed by DOE and NEN Life Science Products, Inc. A separate license agreement to use PNNL's patented process for extracting yttrium-90 from its strontium-90 parent was signed by NEN on October 12, 1998.

Under the lease agreement, DOE receives an immediate fee of $\$ 25 \mathrm{~K}$ and subsequent lease payments based on a percentage of the net sales value of yttrium- 90 sold by NEN. The estimated value of this lease agreement for DOE is approximately $\$ 1 \mathrm{M}$ over a five-year period based on the current yttrium-90 annual sales. Under the license agreement, the management contractor organization for PNNL - the Battelle Memorial Institute - receives an initial fee of $\$ 75 \mathrm{~K}$ and subsequent royalties based on a percentage of the net sales value of Y-90 sold by NEN. The estimated value of this agreement for Battelle is approximately $\$ 500 \mathrm{~K}$ over a five-year license period.

The lease agreement between DOE and NEN allowed a period of six months for transitioning the yttrium-90 production operations from PNNL to NEN laboratories in Billerica, MA. At the beginning of May, 1999, NEN began producing and selling yttrium-90 to commercial customers. PNNL continued to produce yttrium-90 for medical customers involved in Phase 3 clinical trials until early June 1999, in order to allow adequate time for the Food \& Drug Administration to review and approve NEN's Drug Master File and to certify NEN's yttrium-90 procuct as being of suitable quality for use in advanced Phase 3 clinical trials.

Based on the success of the yttrium-90 commercialization activity, PNNL is currently involved in efforts to commercialize other technology that has been developed for the medical application of radioisotopes. For example, negotiations are underway with a private company for use of PNNL's radioactive composite polymer delivery system for treating prostate tumors and other forms of cancer.

\subsection{Future Plans for Isotope Production at the Hanford Fast Flux Test Facility}

\subsubsection{Background information on the FFTF}

The FFTF's original mission was to support liquid metal reactor technology development and reactor safety by providing fuels and materials irradiation services. Although the U.S. liquid metal reactor program ended at about the same time that the FFTF commenced operation in 1982, the reactor continued operation for 10 years as a national research facility to test advanced nuclear fuels and materials, nuclear power plant operating procedures, and active and passive reactor safety technologies. The facility was also used to produce more than 40 different radioisotopes for use in research, medicine, and industry. In addition, FFTF generated tritium for the U.S. fusion research program and supported cooperative, international nuclear research activities. The reactor was shut down in December 1993, and since that time has been in a standby operational condition, pending a decision by DOE on its future use. In May 1999 , the Secretary of Energy announced that a special 90 -day study led by the Director of the Pacific Northwest National Laboratory, Dr. William Madia, would be conducted to establish whether the FFTF should be considered for future missions related to national and international nuclear technology needs. 
This scoping plan for future FFTF missions will be reviewed by NERAC before submission to the Secretary of Energy on August 2, 1999.

\subsubsection{Proposed Future Missions of the FFTF}

Because the FFTF has a large target volume and can provide a high flux of neutrons at energies ranging from thermal to $>1 \mathrm{MeV}$, the facility is suitable for a wide variety of nuclear science and irradiation services missions. As part of the ongoing development of an FFTF scoping plan, these potential missions are being closely evaluated at the time this report is being prepared. The nuclear science and irradiation services provided by FFTF will focus on a core federal role of meeting multiple $21^{\text {st }}$ Century needs, including:

- providing a large and reliable supply of radioisotopes for research, medical, and industrial applications

- promoting safer nuclear technology through reactor safety testing and the development of proliferation-resistant nuclear fuels

- producing power sources for deep-space exploration through the production of plutonium-238 for radioisotope thermoelectric generators (RTGs) and research on compact space reactor technology

- sustaining the nuclear option for power production through testing of fuels, components, and reactor instrumentation

- conducting advanced research and providing services related to the testing of materials for fusion reactors, hardening and testing of materials such as semiconductors, and research on transmutation of nuclear waste materials.

With the establishment of a long-term, stable core federal mission, FFTF would also offer valuable options for private sector users. A significant involvement of commercial, academic, and international users in the future plans for FFTF is realistic, since the reactor previously demonstrated its ability to support multiple users and still achieve a high capacity factor during its ten years of successful operation.

\subsubsection{Capability of the FFTF for Isotope Production}

The FFTF offers several special production advantages relative to other DOE or commercial reactors that are currently in operation in the United States:

1. Neutron Energy Moderation. The FFTF neutron energy spectrum peaks at $\sim 300 \mathrm{keV}$, which provides a significant advantage for the production of several medical isotopes that require a high flux of fast and high-energy neutrons. An example is the production of copper- 67 by an $(n, p)$ reaction with a zinc- 67 target. Through the introduction of energy moderators such as hydrides, the neutron energy spectrum within each target assembly can be moderated over a broad range of energies to provide a high flux of fast or epithermal neutrons. In this manner, the neutron energy at each target location can be tailored to achieve a maximum reaction rate for producing a specific isotope product. 
This flux tailoring capability was demonstrated in tests at the FFTF during the 1980s. Figure 2A shows the composition of a hydrided assembly that was used in a test to simultaneously produce cobalt- 60 and gadolinium-153 during the same irradiation cycle. Figure $2 \mathrm{~B}$ shows the resulting neutron energy spectrum in the hydrided assembly as compared to the unmodified FFTF neutron spectrum. Because several hundred targets can be irradiated simultaneously within the FFTF core region, a wide range of isotope products can be produced during each FFTF operating cycle.

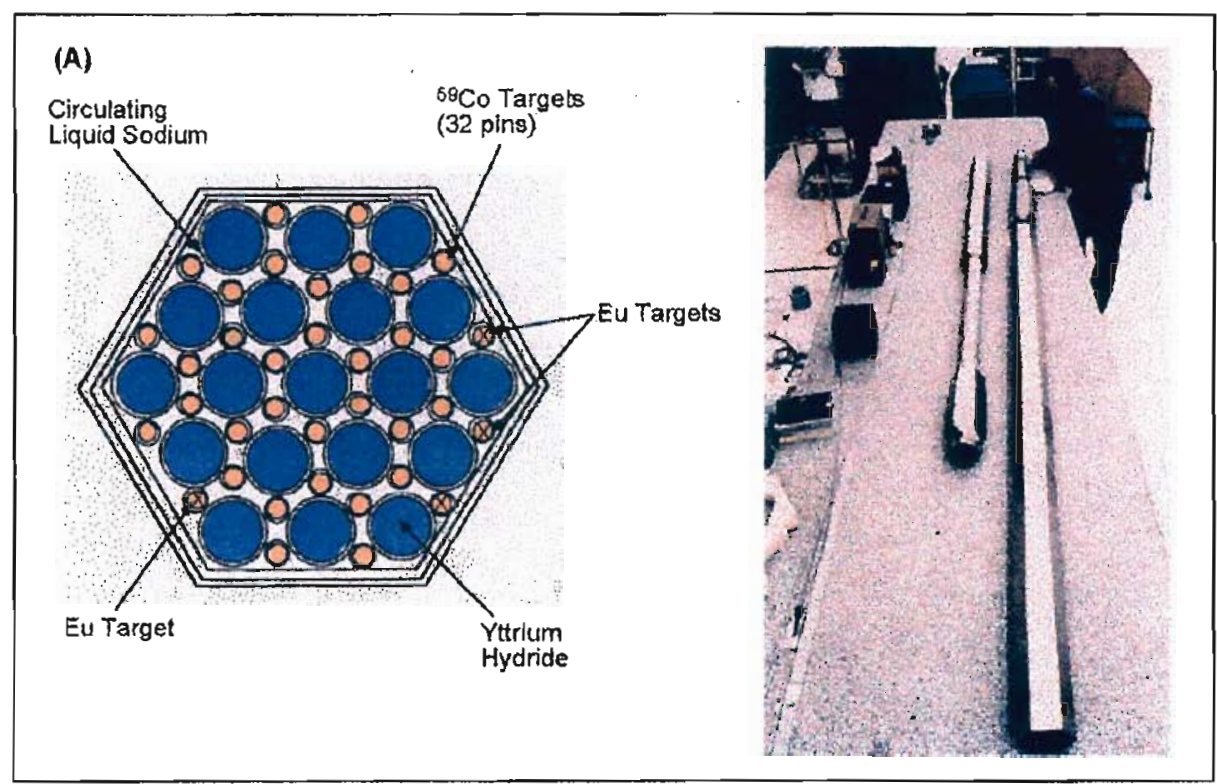

(B)

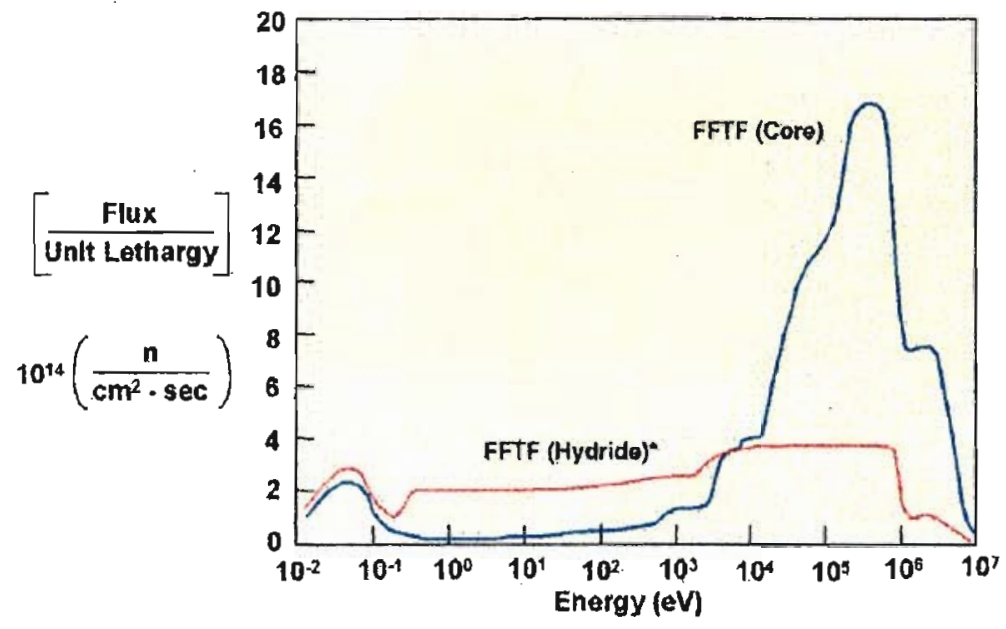

* Yttrium hydride flux tailoring for ${ }^{80} \mathrm{Co}$ and ${ }^{193} \mathrm{Gd}$ production

Figure 2. (A) Hydrided Test Assembly Used in a 1987 FFTF Experiment to Produce Gadolinium-153 and Cobalt-60. (B) Neutron flux profile for hydrided assembly shown in panel (A). 
2. High Neutron Flux. The peak flux within the FFTF core region is $\sim 7 \times 10^{15}$ neutrons $/ \mathrm{cm}^{2} / \mathrm{sec}$ when the reactor is operated at full power, which is higher than that achieved by any other reactor used for isotope production in the United States. As a result, isotopes with high specific activities can be produced in large quantities during irradiation cycles that range from 10 days (for short-lived medical isotopes) to one year. Figure 3 illustrates the high neutron flux capabilities of FFTF relative to other U.S. reactors.

3. Large Target Volume. The core volume within the FFTF reactor vessel is $\sim 1,000$ liters, which is twice as large as the core volumes of the other existing DOE reactors combined. This feature provides a production advantage for isotopes that are needed in bulk quantities, or for which a small production cross-section must be offset by the irradiation of large target masses.

During the FFTF's ten years of operation, more than 40 different medical, industrial, and research isotopes were produced. The reactor also demonstrated the capability to produce multiple isotope species during the same irradiation cycle. As the demand for medical isotopes increases, the FFTF could meet multiple isotope production needs while supporting other nuclear science and irradiation services missions.

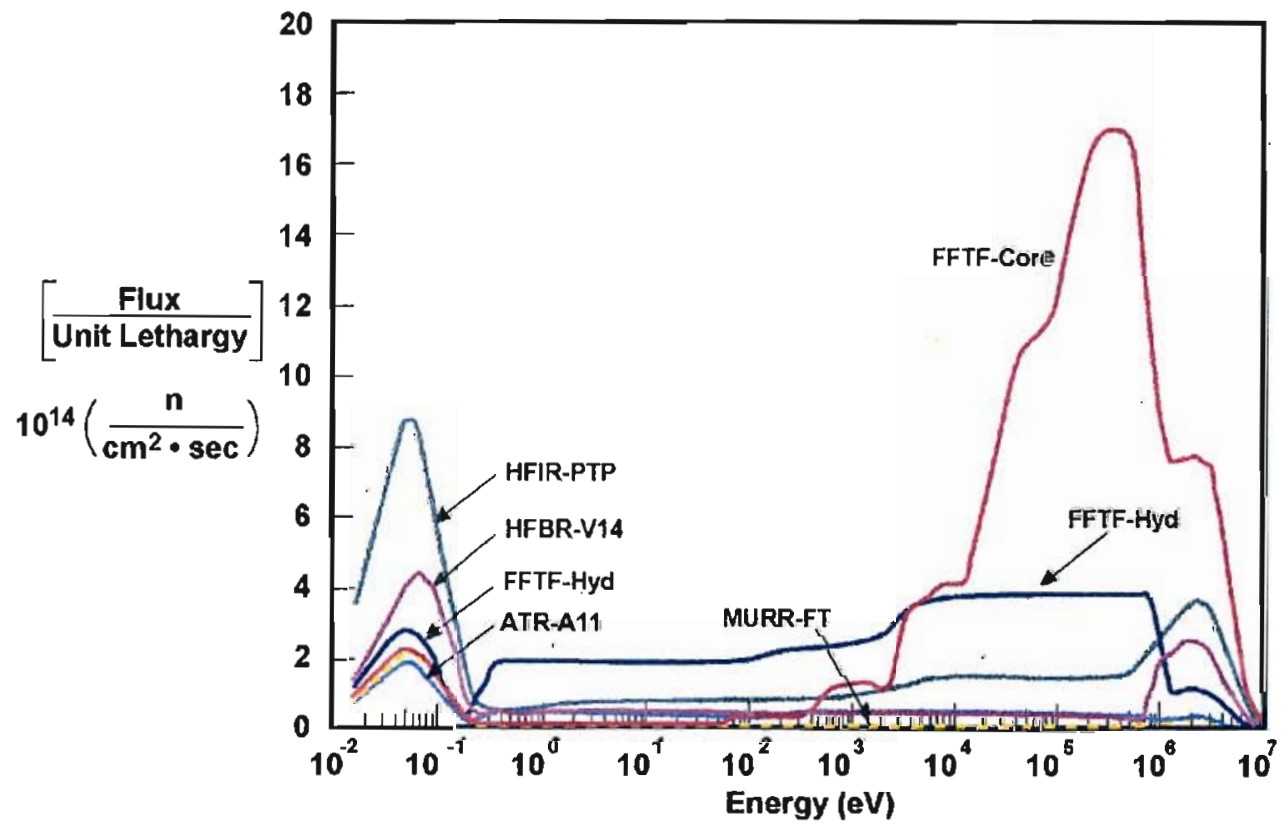

Figure 3. Comparison of FFTF Neutron Spectra With and Without Yttrium Hydride (Hyd) Moderator Pins; Also Shown are Neutron Spectra From the Core Regions of the High Flux Isotope Reactor (HFIR, Oak Ridge National Laboratory), the High Flux Beam Reactor (HFBR, Brookhaven National Laboratory), the Advanced Test Reactor (ATR, Idaho National Environmental and Engineering Laboratory), and the Missouri University Research Reactor (MURR). 


\subsubsection{Candidate Medical Isotopes to be Produced at FFTF and Comparison with Market Demand and Other DOE Reactor Capabilities}

In planning for a future isotope production mission at FFTF, consideration has been given to the projected future demand for a broad range of radioisotopes required for medical and commercial applications. The present and future availability of these isotopes from domestic sources has been analyzed, as well as the FFTF's capability to supplement the supply of these isotopes to meet the projected future demand. From these analyses, together with recent forecasts of the medical isotopes market such as those conducted by Frost and Sullivan ${ }^{1}$ and the Medical University of South Carolina, ${ }^{2}$ it is apparent that the greatest challenge in meeting the market requirements over the coming two decades will be in the area of therapeutic medical isotopes. A focus of the planning activities for the future FFTF radioisotope production mission has therefore been placed on these isotopes, several of which are currently unavailable, or available only in limited quantities, from sources in the U.S. and worldwide.

For initial planning purposes, a set of 30 medical isotopes was selected on the basis of information obtained from several sources, including (1) the above-mentioned medical market forecasts, (2) reviews of the medical literature and the $\sim 120$ ongoing clinical trials that utilize radioisotopes for the treatment of cancer and other diseases, and (3) the report of an expert panel that was formed by DOE in 1998 to assess the future demand for medical isotopes. ${ }^{3}$ These 30 isotopes are listed in Table 1, along with a description of their medical applications. These applications primarily involve the diagnosis and treatment of three major classes of disease - cancer, vascular disease (arterial restenosis), and arthritis. Some of these isotopes have both diagnostic and therapeutic applications (e.g., iodine-131). It should also be noted that several of the isotopes serve as "generators" for other therapeutic medical isotopes that are obtained as decay products [e.g., tungsten-188 for rhenium-188, thorium-229 for actinium-225 (and bismuth-213), thorium-228 for bismuth-212, and actinium-227 for radium-223]. Table 1 also presents the reaction process used to transmute the target isotope through neutron irradiation to make the desired medical isotope product. Three types of reaction processes are considered, namely, the capture of a neutron with ejection of either a gamma ray or a proton, and inelastic excitation which transforms the target isotope nucleus to an excited isomeric state.

From an analysis of the production requirements for these 30 reactor-generated isotopes, it becomes quickly evident that several of them have small ( $<5$ barn) production cross-sections and require target irradiation with fast or high-energy neutrons. The cross-sections and neutron energy requirements for the 30 isotopes listed in Table 1 are depicted schematically in Figure 4. It is apparent from this representation of the isotope production requirements that the FFTF, because of its high flux of fast neutrons and the ability to perform flux tailoring using hydride energy moderation, is ideally suited for the efficient production of a majority of the medical isotopes listed in Table 1.

1 "FFTF Medical Isotopes Market Study (2001-2020)," Frost and Sullivan, Inc., Mountain View, California; Pacific Northwest National Laboratory report PNNL-11774, Richland, Washington (1997).

2 "Evaluation of Medical Radionuclide Production with the Accelerator Production of Tritium (APT) Facility," Medical University of South Carolina report (July 15, 1997).

3 Expert Panel Report: "Forecast Future Demand for Medical Isotopes," DOE Cooperative Program Project \#130, final report (April 1998). 
Table 1. Thirty Candidate Medical Isotopes for Production at FFTF

\begin{tabular}{|c|c|c|}
\hline Medical Isotope & Medical Applications & Reactions \\
\hline $\begin{array}{l}\text { Actinium-227 } \\
\text { (Ac-227) }\end{array}$ & $\begin{array}{l}\text { Parent of Ra-223 [monoclonal antibody attachment used for cancer } \\
\text { treatment by radioimmunotherapy (RIT)] }\end{array}$ & $\operatorname{Ra} 226(n, \gamma) \operatorname{Ra} 227 / A c 227$ \\
\hline $\begin{array}{l}\text { Gold-198 } \\
\text { (Au-198) }\end{array}$ & $\begin{array}{l}\text { Mini-gun, treating ovarian cancer, prostate cancer, brain cancer, } \\
\text { intracavity therapy }\end{array}$ & Au197(n, $\gamma)$ Au198 \\
\hline $\begin{array}{l}\text { Cadmium-109 } \\
(\text { Cd-109) }\end{array}$ & Cancer detection, pediatric imaging & $\begin{array}{c}\text { Cd108(n,y)Cd109 } \\
\text { Or } \\
\operatorname{Ag} 107(\mathrm{n}, \gamma) \operatorname{Cd} 108 \\
\operatorname{Cd} 108(\mathrm{n}, \gamma) \operatorname{Cd} 109\end{array}$ \\
\hline $\begin{array}{l}\text { Copper-64 } \\
(\mathrm{Cu}-64)\end{array}$ & $\begin{array}{l}\text { SPECT imaging, dosimetry studies, cerebral and myocardial blood } \\
\text { flow, colorectal cancer therapy }\end{array}$ & Zn64(n,p)Cu64 \\
\hline $\begin{array}{l}\text { Copper-67 } \\
(\mathrm{Cu}-67)\end{array}$ & $\begin{array}{l}\text { Cancer treatment/diagnostics, radioimmunotherapy (RIT), planar } \\
\text { imaging, SPECT imaging }\end{array}$ & Zn67(n,p)Cu67 \\
\hline $\begin{array}{l}\text { Gadolinium-153 } \\
\text { (Gd-153) }\end{array}$ & Dual photon source, osteoporosis detection, SPECT imaging & $\begin{array}{l}\text { Eu }(n, \gamma) \text { Eu } 152 / G d 152 \\
\text { Gd152 (n, } \gamma) \text { Gd153 }\end{array}$ \\
\hline $\begin{array}{l}\text { Holmium-166 } \\
\text { (Ho-166) }\end{array}$ & $\begin{array}{l}\text { Treatment of rheumatoid arthritis, radiolabeling and monoclonal } \\
\text { antibody techniques }\end{array}$ & Ho165(n,y)Ho166 \\
\hline $\begin{array}{l}\text { Iodine-125 } \\
(\mathrm{I}-125)\end{array}$ & $\begin{array}{l}\text { Osteoporosis detection, diagnostic imaging, tracer drugs, } \\
\text { monoclonal antibodies, brain cancer treatment (I-131 replacement), } \\
\text { radiolabeling, tumor imaging, mapping of receptors in the brain, } \\
\text { interstitial radiation therapy, brachytherapy for treatment of } \\
\text { prostate cancer, determination of glomerular filtration rate (GFR), } \\
\text { determination of plasma volume, detection of deep vein thrombosis } \\
\text { of the legs }\end{array}$ & $\mathrm{Xe124(n, \gamma )Xe125/125}$ \\
\hline $\begin{array}{l}\text { Iodine-131 } \\
(1-131)\end{array}$ & $\begin{array}{l}\text { Lymphoid tissue tumor/hyperthyroidism treatment, antibody } \\
\text { labeling, brain biochemistry in mental illness, diagnosis of thyroid } \\
\text { disorders by gamma camera imaging or counting, radio- } \\
\text { immunotherapy, imaging, cellular dosimetry, adrenal medulla } \\
\text { scintigraphy, treatment of Grave's disease, treatment of goiters, } \\
\text { treatment of prostate cancer, treatment of hepatocellular } \\
\text { carcinoma, treatment of melanoma, locate metastatic lesions, } \\
\text { treatment of neuroblastoma and malignant pheochromocytoma, } \\
\text { internal (systemic) radiation therapy, treatment of thyroid } \\
\text { carcinoma, study of kidney functions, construction of renogram, } \\
\text { adrenal cortex imaging, investigations of hepatobillary function, } \\
\text { determination of plasma volume }\end{array}$ & Te130(n,y)I131 \\
\hline $\begin{array}{l}\text { Iridium-192 } \\
\text { (Ir-192) }\end{array}$ & $\begin{array}{l}\text { Brachytherapy, brain and spinal cord tumor treatment, restenosis } \\
\text { stents, seed implants for breast and prostate tumors }\end{array}$ & $\operatorname{Ir} 191(\mathbf{n}, \gamma) \operatorname{Ir} 192$ \\
\hline $\begin{array}{l}\text { Lutetium-177 } \\
(\mathrm{Lu}-177)\end{array}$ & Heart disease treatment (restenosis therapy), cancer therapy (RIT) & Lu176(n, $\gamma)$ Lu177 \\
\hline $\begin{array}{l}\text { Molybdenum-99 } \\
\text { (Mo-99) }\end{array}$ & $\begin{array}{l}\text { Parent for Tc-99m generator used for brain, liver, lungs, heart } \\
\text { imaging }\end{array}$ & Mo98(n,y)Mo99 \\
\hline $\begin{array}{l}\text { Osmium-194 } \\
\text { (Os-194) }\end{array}$ & Monoclonal antibody attachment used for cancer treatment (RIT) & $\begin{array}{l}\text { Os192(n, }, \text { Os193 } \\
\text { Os193(n, } \gamma) \text { Os194 } \\
\end{array}$ \\
\hline $\begin{array}{l}\text { Phosphorus-32 } \\
\text { (P-32) }\end{array}$ & $\begin{array}{l}\text { Polycythemia rubra vera (blood cell disease) and leukemia } \\
\text { treatment, bone disease diagnosis/treatment, SPECT imaging of } \\
\text { tumors, pancreatic and liver cancer treatment, radiolabeling, } \\
\text { labeling nucleic acids for in vitro research, diagnosis of superficial } \\
\text { tumors, cardiovascular disease treatment (restenosis), intracavity } \\
\text { therapy }\end{array}$ & $\begin{array}{l}\text { S32(n,p)P32 } \\
\text { Or } \\
\text { P32(n, } \gamma) P 33\end{array}$ \\
\hline
\end{tabular}


Table 1. (Contd)

\begin{tabular}{|c|c|c|}
\hline Medical Isotope & Medical Applications & Reactions \\
\hline $\begin{array}{l}\text { Phosphorus-33 } \\
\text { (P-33) }\end{array}$ & $\begin{array}{l}\text { Leukemia treatment, bone disease diagnosis/treatment, SPECT } \\
\text { imaging of tumors, radiolabeling, restenosis treatment }\end{array}$ & S33(n,p)P33 \\
\hline $\begin{array}{l}\text { Palladium-103 } \\
\text { (Pd-103) }\end{array}$ & Prostate cancer treatment & Pd102 (n, $\gamma) \operatorname{Pd} 103$ \\
\hline $\begin{array}{l}\text { Platinum-195m } \\
\text { (Pt-195m) }\end{array}$ & $\begin{array}{l}\text { Noninvasive monitoring of drug biodistribution and metabolism, } \\
\text { studies with intra-arterial Pt-195m-cisplatin }\end{array}$ & $\begin{array}{l}\text { Pt195(n,n')Pt195m } \\
\text { Or } \\
\text { Pt194(n, } \gamma) \text { Pt195m } \\
\end{array}$ \\
\hline $\begin{array}{l}\text { Rhenium-186 } \\
\text { (Re-186) }\end{array}$ & $\begin{array}{l}\text { Cancer treatment/diagnostics, monoclonal antibodies, bone cancer } \\
\text { pain relief, treatment of rheumatoid arthritis, treatment of prostate } \\
\text { cancer, bone cancer pain relief }\end{array}$ & $\operatorname{Re} 185(\mathrm{n}, y) \operatorname{Re} 186$ \\
\hline $\begin{array}{l}\text { Scandium-47 } \\
(\mathrm{Sc}-47)\end{array}$ & Bone cancer pain relief, radioimmunotherapy (RIT) & Ti47(n,p)Sc47 \\
\hline $\begin{array}{l}\text { Selenium-75 } \\
\text { (Se-75) }\end{array}$ & $\begin{array}{l}\text { Radiotracer used in brain studies, imaging of adrenal cortex by } \\
\text { gamma-scintigraphy, lateral locations of steroid secreting tumors, } \\
\text { pancreatic scanning, detection of hyperactive parathyroid glands, } \\
\text { measure rate of bile acid loss from the endogenous pool }\end{array}$ & $\operatorname{Se} 74(n, \gamma) \operatorname{Se} 75$ \\
\hline $\begin{array}{l}\text { Samarium-145 } \\
(\text { Sm-145) }\end{array}$ & Treatment of ocular cancer & $\operatorname{Sm144(n,\gamma )\operatorname {Sm}145}$ \\
\hline $\begin{array}{l}\text { Samarium-153 } \\
(\mathrm{Sm}-153)\end{array}$ & $\begin{array}{l}\text { Cancer treatment/diagnostics, bone cancer pain relief, treatment of } \\
\text { leukemia }\end{array}$ & $\operatorname{Sm} 152(\mathrm{n}, \gamma) \operatorname{Sm} 153$ \\
\hline $\begin{array}{l}\text { Strontium-85 } \\
\text { (Sr-85) }\end{array}$ & Detection of bone lesions, brain scans & $\operatorname{Sr} 84(\mathrm{n}, \gamma) \operatorname{Sr} 85$ \\
\hline $\begin{array}{l}\text { Strontium-89 } \\
\text { (Sr-89) }\end{array}$ & $\begin{array}{l}\text { Bone cancer pain relief, treatment of prostate cancer, treatment of } \\
\text { multiple myeloma, osteoblastic therapy, potential agent for } \\
\text { treatment of bone metastases from prostate and breast cancer }\end{array}$ & $\begin{array}{l}\text { Sr88(n, } \gamma) \operatorname{Sr} 89 \\
\text { Or } \\
\text { Y89(n,p)Sr89 }\end{array}$ \\
\hline $\begin{array}{l}\text { Thorium-228 } \\
\text { (Th-228) }\end{array}$ & Cancer treatment (RIT), monoclonal antibodies, parent of Bi-212 & $\begin{array}{l}\mathrm{Ra} 226(\mathrm{n}, \gamma) \operatorname{Ra} 227 / \mathrm{Ac} 227 \\
\mathrm{Ac} 227(\mathrm{n}, \gamma) \operatorname{Ac228} / \mathrm{Th} 228 \\
\end{array}$ \\
\hline $\begin{array}{l}\text { Thorium-229 } \\
\text { (Th-229) }\end{array}$ & $\begin{array}{l}\text { Grandparent of Bi-213 (alpha emitter used in cancer treatment } \\
\text { (RIT)), parent of Ac-225 }\end{array}$ & $\begin{array}{l}\operatorname{Ra} 226(n, \gamma) \operatorname{Ra} 227 / A c 227 \\
\text { Ac227(n, } \gamma) \operatorname{Ac} 228 / \operatorname{Th} 228 \\
\operatorname{Th} 228(n, \gamma) \operatorname{Th} 229\end{array}$ \\
\hline $\begin{array}{l}\text { Tin-117m } \\
(\mathrm{Sn}-117 \mathrm{~m})\end{array}$ & Bone cancer pain relief & $\begin{array}{l}\text { Sn117(n,n')Sn117m } \\
\text { Or } \\
\text { Sn } 116(n, \gamma) \text { Sn } 117 m \\
\end{array}$ \\
\hline $\begin{array}{l}\text { Tungsten-188 } \\
\text { (W-188) }\end{array}$ & Cancer treatment (RIT), parent for $\mathrm{Re}-188$ generator & $\begin{array}{l}\text { W186(n, }, \text { W187 } \\
\text { W187(n,y)W188 } \\
\end{array}$ \\
\hline $\begin{array}{l}\text { Xenon-127 } \\
\text { (Xe-127) }\end{array}$ & $\begin{array}{l}\text { Neuroimaging for brain disorders, research on variety of } \\
\text { neuropsychiatric disorders (especially schizophrenia and } \\
\text { dementia), higher resolution SPECT studies with lower patient } \\
\text { dose, lung imaging evaluation of pulmonary ventilation, indicator } \\
\text { for measurement of local cerebral blood flow }\end{array}$ & $\mathrm{Xe126}(\mathrm{n}, \gamma) \mathrm{Xe127}$ \\
\hline $\begin{array}{l}\text { Yttrium-91 } \\
(Y-91)\end{array}$ & Cancer treatment (RIT), cellular dosimetry & $\mathrm{Zr91(n,p)Y91}$ \\
\hline
\end{tabular}




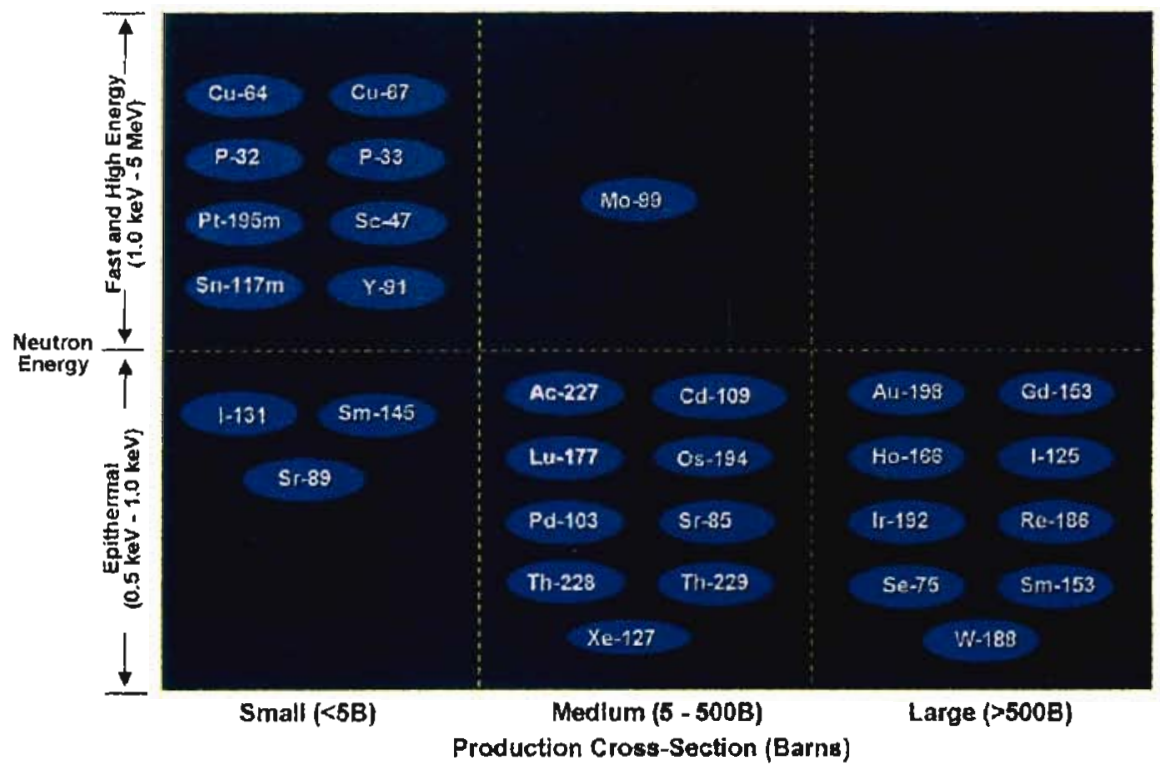

Figure 4. Neutron Energy Requirements for Optimum Production of Reactor-Generated Medical Isotopes

Further evidence for the advantages of using a reactor such as FFTF to produce these 30 medical isotopes is provided by a calculation of the ratio of the resonance integral to the thermal cross-section for isotope production. These calculations are presented in Table 2, from which it is apparent that the majority of isotopes listed in Table 1 have a ratio of the resonance integral to the thermal cross-section that is significantly greater than one. Under this condition, the high fluxes of fast and epithermal neutrons provided by FFTF offer distinct production advantages.

For the 30 isotopes listed in Table 1, extensive calculations have been made of the rate of production that can be achieved in FFTF operating at power levels up to $400 \mathrm{MW}$. These calculations have been made using neutron flux data obtained by an MCNP computer code. ${ }^{4}$ The calculations involve combining neutron flux data with cross-section data obtained primarily from the BNL-325 data source and the ENDF/B cross-section data files. ${ }^{6}$

${ }^{4}$ Briesmeister, J.F., "Monte Carlo Neutron Particle Code (MCNP): A General Monte Carlo N-Particle Transport Code, Version 4A," Los Alamos National Laboratory report (November 1993).

${ }^{5}$ Mughabghab, S.F., "Neutron Cross Sections Volume 1: Neutron Resonance Parameters and Thermal Cross Sections," Academic Press, New York (1984).

${ }^{6}$ McLane, V. et al., "ENDF-201 ENDF/B-VI Summary Documentation Supplement I; ENDF/HE-VI Summary Documentation," Brookhaven National Laboratory Rep. No. BNL-NCS-177541 (1996). 
Table 2. FFTF Production Advantages for Medical Isotopes

\begin{tabular}{|c|c|c|c|c|}
\hline Isotope & $\begin{array}{c}\text { Target } \\
\text { Material }\end{array}$ & $\left(\mathbf{I}_{\gamma} / \sigma_{\mathrm{t}}\right)^{(\mathbf{a})}$ & $\begin{array}{c}\text { Cross- } \\
\text { Section }^{(b)}\end{array}$ & $\begin{array}{c}\text { Optimum } \\
\text { Neutron Energy }^{(c)}\end{array}$ \\
\hline Ac- 227 & Ra-226 & 21.5 & $\mathrm{M}$ & $\mathrm{E}$ \\
\hline $\mathrm{Au}-198$ & $\mathrm{Au}-197$ & 15.7 & $\mathrm{~L}$ & $\mathrm{E}$ \\
\hline $\mathrm{Cd}-109$ & Cd-108 & 15.0 & $\mathrm{M}$ & $E$ \\
\hline $\mathrm{Cu}-64$ & $\mathrm{Zn}-64$ & N/A & $S$ & $\mathrm{H}$ \\
\hline $\mathrm{Cu}-67$ & $\mathrm{Zn}-67$ & N/A & $S$ & $\mathrm{H}$ \\
\hline Gd-153 & Natural Eu & 0.9 & $\mathrm{~L}$ & $E$ \\
\hline Ho-166 & Ho-165 & 11,1 & $\mathrm{~L}$ & $E$ \\
\hline $\mathrm{I}-125$ & $\mathrm{Xe}-124$ & 2.5 & $\mathrm{~L}$ & $E$ \\
\hline $\mathrm{I}-131$ & Te-130 & $2 . \overline{5}$ & $S$ & $E$ \\
\hline Ir-192 & Ir-191 & 5.5 & $\mathrm{~L}$ & $E$ \\
\hline Lu-177 & Lu-175 & 34.0 & $\mathbf{M}$ & $E$ \\
\hline Mo-99 & Mo-98 & 50.0 & $\mathrm{M}$ & $F$ \\
\hline Os-194 & Os-192 & 2.5 & $\mathbf{M}$ & $\mathrm{E}$ \\
\hline $\mathrm{P}-32$ & S-32 & N/A & $\mathrm{S}$ & $\mathbf{H}$ \\
\hline P-33 & $\mathrm{S}-33$ & N/A & $S$ & $\mathrm{H}$ \\
\hline Pd-103 & Pd-102 & 3.3 & $\mathbf{M}$ & $E$ \\
\hline Pt-195m & Pt-195 & N/A & $S$ & $\mathrm{~F}$ \\
\hline $\mathrm{Re}-186$ & Re-185 & 15.2 & $\mathrm{~L}$ & $\mathrm{E}$ \\
\hline Sc-47 & Ti-47 & N/A & $S$ & $\mathrm{H}$ \\
\hline $\mathrm{Se}-75$ & Se-74 & 12.5 & $\mathrm{~L}$ & $E$ \\
\hline Sm-145 & Sm-144 & 1.5 & $S$ & $\mathrm{E}$ \\
\hline Sm-153 & Sm-152 & 14.4 & $\mathrm{~L}$ & $\mathrm{E}$ \\
\hline $\mathrm{Sn}-117 \mathrm{~m}$ & Sn-117 & N/A & $S$ & $\mathrm{~F}$ \\
\hline Sr-85 & $\mathrm{Sr}-84$ & 13.8 & $\mathrm{M}$ & $E$ \\
\hline Sr-89 & Sr-88 & 10.3 & $S$ & $E$ \\
\hline Th-228 & $\mathrm{Ra}-226$ & 21.5 & $\bar{M}$ & $\mathrm{E}$ \\
\hline Th-229 & $\mathrm{Ra}-226$ & 21.5 & $\mathrm{M}$ & $E$ \\
\hline W-188 & W-186 & 12.9 & $\mathrm{~L}$ & $E$ \\
\hline$\overline{\mathrm{Xe}}-127$ & $\mathrm{Xe}-126$ & 17.1 & $\mathbf{M}$ & $E$ \\
\hline $\mathrm{Y}-91$ & $\mathrm{Zr}-91$ & N/A & $\bar{S}$ & $\mathrm{H}$ \\
\hline \multicolumn{5}{|c|}{$\begin{array}{l}\text { (a) Ratio of resonance integral }\left(\mathrm{I}_{\gamma}\right) \text { to thermal cross-section }\left(\sigma_{\mathrm{t}}\right) \text {. A ratio }>1 \text { indicates } \\
\text { production advantages at neutron energies above thermal. Ratios marked N/A are } \\
\text { associated with reactions involving fast/high energy neutrons that do not occur with } \\
\text { thermal neutrons. } \\
\text { (b) Cross-sections (resonance integrals) characterized as } \mathrm{S} \text { (small, }<5 \text { barns), } \mathrm{M} \\
\text { (medium, } 5 \text { - } 500 \text { barns), and } \mathrm{L} \text { (large, }>500 \text { barns). } \\
\text { (c) Neutron energies represented as T (thermal, }<0.5 \mathrm{eV} \text { ), E (epithermal, } 0.5 \mathrm{eV}-1 \\
\mathrm{keV}, \mathrm{F} \text { (fast, } 1 \mathrm{keV}-1 \mathrm{MeV} \text { ), and } \mathrm{H} \text { (high-energy, }>1 \mathrm{MeV} \text { ). }\end{array}$} \\
\hline
\end{tabular}


For purposes of calculating the FFTF production rates of the 30 isotopes listed in Table 1, a representative core map for FFTF operations in a future multiprogram mission has been developed. The important features of this core configuration for medical isotope production are:

- One assembly located in Row 4 and two assemblies in Row 6 are available for production of shortlived isotopes ( $\mathrm{t}_{1 / 2} \leq 2$ weeks) that require the removal of targets using a rapid radioisotope retrieval (R3) system while the reactor is at full power.

- A continuous-flow gas line is available in Row 2 for the production of products such as iodine-125 (from a xenon-124 gas target).

- A total of 3 to 12 positions for the production of longer-lived isotope products are available in Row 6 of the core region; these products would be produced using a long-term irradiation vehicle (LIV) for the targets, which would be removed only at the end of an operating cycle when the reactor power is reduced for scheduled maintenance procedures. A preliminary analysis indicated that at least 9 , and possibly 12, LIVs in Row 6 could be used for medical isotope production without significantly impacting other FFTF irradiation services.

In the current model of the FFTF core configuration, $48 \mathrm{LIV}$ assemblies in Row 9 (the outermost row of the reflector region) can be dedicated to the production of cobalt- 60 for sale to companies that manufacture sterilization equipment and medical teletherapy units. Based on the calculated cobalt- 60 production yield for three 100-day FFTF operating cycles, $\sim 4$ million curies of this isotope can be produced annually.

Although the FFTF has a rated power of $400 \mathrm{MW}$, initial operations in the proposed future multiprogram mission will be conducted at a power level of $100 \mathrm{MW}$. This choice of power level will permit the use of existing reactor fuel supplies for at least five years, and will extend the reactor's lifetime well beyond the current estimate of 22 years for operation at a 400-MW power level. Accordingly, estimates of medical isotope production rates presented in this report are for FFTF operations at $100 \mathrm{MW}$.

Table 3 presents a summary of the calculated rates of production in FFTF of the 30 medical isotopes listed in Table 1. These calculations were made for irradiation cycles ranging from 10 days for the shortest lived isotope species to 100 days for the longer-lived isotopes. It is assumed that the typical FFTF operating cycle between scheduled maintenance procectures will be approximately 100 days. The target masses shown in Table 3 were selected on the basis of available volume in the R3 irradiation vehicles used for short-lived isotope products, and also on the basis of the availability and cost of enriched target materials. In nearly all of the target materials the burnout rate calculated for typical irradiation cycles is small, thereby permitting reuse of the residual target materials following radiochemical separation of the product isotopes. The calculations presented in Table 3 also take into account the use of hydrided assemblies to provide neutron energy moderation for optimizing the production of isotopes that have large cross-sections in the epithermal range. In addition, target selfshielding effects were calculated and have been taken into account in the isotope production rates presented in Table 3. 
Table 3. Production Rates at $100 \mathrm{MW}$ of 30 FFTF Medical Isotopes

\begin{tabular}{|c|c|c|c|c|c|c|c|c|}
\hline & $\begin{array}{l}\text { Product } \\
\text { Isotope }\end{array}$ & Half Life & $\begin{array}{c}\text { Primary } \\
\text { Target } \\
\text { Isotope } \\
\end{array}$ & 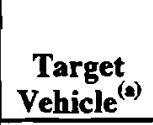 & $\begin{array}{l}\text { Irradiation } \\
\text { Time (days) }\end{array}$ & $\begin{array}{l}\text { Primary Target } \\
\text { Isotope Mass (g) }\end{array}$ & $\begin{array}{c}\text { Product Isotope } \\
\text { Specific } \\
\text { Activity (Ci/g) }\end{array}$ & $\begin{array}{c}\text { Product Isotope } \\
\text { Activity } \\
\text { Produced (Ci) }\end{array}$ \\
\hline 1 & Ac- 227 & 21.8 years & $\mathrm{Ra}-226$ & LN-H & 100 & $3.3 \mathrm{E}+01$ & $7.2 \mathrm{E}+01$ & $3.4 \mathrm{E}+01$ \\
\hline 2 & Au-198 & 2.69 days & Au-197 & R3-H & 10 & $1.4 \mathrm{E}-01$ & $1.3 \mathrm{E}+03$ & $7.9 \mathrm{E}+01$ \\
\hline 3 & $\mathrm{Cd}-109$ & 462.0 days & Cd-108 & LIV-H & 100 & $1.0 \mathrm{E}+03$ & $2.1 \mathrm{E}+00$ & $6.5 \mathrm{E}+02$ \\
\hline 4 & $\mathrm{Cu}-64$ & 12.7 hours & $\mathrm{Zn}-64$ & R3 & 10 & $1.1 \mathrm{E}+01$ & $3.8 E+06$ & $9.6 \mathrm{E}+01$ \\
\hline 5 & $\mathrm{Cu}-67$ & 2.58 days & $\mathrm{Zn}-67$ & R3 & 10 & $9.3 \mathrm{E}+01$ & $7.5 \mathrm{E}+05$ & $3.7 \mathrm{E}+00$ \\
\hline 6 & Gd-153 & 242 days & Natural Eu & LIV-H & 100 & $1.7 \mathrm{E}+03$ & $3.4 \mathrm{E}+01$ & $1.1 \mathrm{E}+03$ \\
\hline 7 & Ho-166 & 1.12 days & Ho-165 & R3-H & 10 & $1.3 \mathrm{E}-01$ & $3.1 \mathrm{E}+02$ & $1.7 \mathrm{E}+01$ \\
\hline 8 & I-125 & 60.1 days & $\mathrm{Xe}-124$ & Gas Line & 100 & $4.3 \mathrm{E}+00$ & $1.7 \mathrm{E}+04$ & $2.4 E+03$ \\
\hline 9 & I-131 & 8.04 days & $\mathrm{Te}-130$ & R3-H & 25 & $1.4 \mathrm{E}+02$ & $5.5 \mathrm{E}+04$ & $2.6 \mathrm{E}+02$ \\
\hline 10 & Ir-192 & 73.8 days & Ir-191 & LNV & 100 & $1.5 \mathrm{E}+04$ & $1.4 \mathrm{E}+02$ & $3.5 \mathrm{E}+03$ \\
\hline 11 & Lu-177 & 6.68 days & Lu-175 & R3-H & 25 & $2.7 \mathrm{E}-03$ & $2.8 \mathrm{E}+03$ & $4.0 \mathrm{E}-01$ \\
\hline 12 & Mo-99 & 2.75 days & Mo-98 & R3-H & 10 & $2.1 E+01$ & $5.5 \mathrm{E}+01$ & $1.0 \mathrm{E}+03$ \\
\hline 13 & Os-194 & 6.0 years & Os-192 & LIV & 100 & $2.3 \mathrm{E}+05$ & $5.6 \mathrm{E}-05$ & $2.2 \mathrm{E}+00$ \\
\hline 14 & P-32 & 14.3 days & $S-32$ & R3 & 25 & $2.0 \mathrm{E}+01$ & $2.8 \mathrm{E}+05$ & $3.5 \mathrm{E}+01$ \\
\hline 15 & P-33 & 25.3 days & $S-33$ & LIV & 100 & $7.1 \mathrm{E}+00$ & $1.5 \mathrm{E}+05$ & $6.5 \mathrm{E}+01$ \\
\hline 16 & Pd-103 & 17.0 days & Pd-102 & R3-H & 25 & $5.4 \mathrm{E}+01$ & $1.5 \mathrm{E}+03$ & $1.2 \mathrm{E}+03$ \\
\hline 17 & Pt-195m & 4.02 days & Pt-195 & R3-H & 25 & $5.0 \mathrm{E}+01$ & $5.6 \mathrm{E}+01$ & $1.2 \mathrm{E}+02$ \\
\hline 18 & $\operatorname{Re}-186$ & 3.78 days & $\operatorname{Re}-185$ & R3-H & 25 & $1.5 \mathrm{E}+01$ & $4.5 \mathrm{E}+01$ & $3.0 \mathrm{E}+03$ \\
\hline 19 & Sc-47 & 3.35 days & $\mathrm{Ti}-47$ & R3 & 10 & $7.2 \mathrm{E}+01$ & $8.2 \mathrm{E}+05$ & $1.8 \mathrm{E}+01$ \\
\hline 20 & $\mathrm{Se}-75$ & 120.0 days & $\mathrm{Se}-74$ & LIV-H & 100 & $3.0 \mathrm{E}-01$ & $5.9 \mathrm{E}+02$ & $1.7 \mathrm{E}+01$ \\
\hline 21 & Sm-145 & 340 days & Sm-144 & LIV-H & 100 & $1.1 \mathrm{E}+01$ & $9.4 \mathrm{E}+00$ & $1.1 \mathrm{E}+01$ \\
\hline 22 & Sm-153 & 1.93 days & $\mathrm{Sm}-152$ & $\overline{\mathrm{R} 3-\mathrm{H}}$ & 10 & $8.3 \mathrm{E}-03$ & $4.6 \mathrm{E}+02$ & $3.5 \mathrm{E}+01$ \\
\hline 23 & $\mathrm{Sn}-117 \mathrm{~m}$ & 13.6 days & Sn-116 & R3-H & 25 & $2.7 E+00$ & $3.6 \mathrm{E}+01$ & $4.4 \mathrm{E}+01$ \\
\hline 24 & Sr-85 & 64.8 days & Sr-84 & LIV-H & 100 & $3.4 \mathrm{E}+03$ & $1.2 \mathrm{E}+02$ & $2.0 \mathrm{E}+03$ \\
\hline 25 & Sr-89 & 50.5 days & Sr-88 & $\overline{\mathrm{LIV}}-\mathrm{H}$ & 100 & $2.5 \mathrm{E}+02$ & $7.2 \mathrm{E}-01$ & $1.4 \mathrm{E}+02$ \\
\hline 26 & Th-228 & 1.91 years & Ra-226 & LJV-H & 100 & $3.3 \mathrm{E}+01$ & $6.4 \mathrm{E}+02$ & $1.4 \mathrm{E}+02$ \\
\hline 27 & $\mathrm{Th}-229$ & 7300 years & $\mathrm{Ra}-226$ & LIV-H & 100 & $3.3 \mathrm{E}+01$ & $4.8 \mathrm{E}-02$ & $2.7 \mathrm{E}-02$ \\
\hline 28 & W-188 & 69.4 days & W-186 & LIV-H & 100 & $3.0 \mathrm{E}+04$ & $1.1 \mathrm{E}+00$ & $5.5 \mathrm{E}+03$ \\
\hline 29 & Xe-127 & 36.4 days & $\mathrm{Xe}-126$ & $\overline{\mathrm{LIV}}$ & 100 & $1.2 \mathrm{E}+00$ & $3.4 \mathrm{E}+02$ & $6.5 \bar{E}+01$ \\
\hline 30 & Y-91 & 58.5 days & $\mathrm{Zr}-91$ & LIV & 100 & $9.5 \mathrm{E}+03$ & $2.5 \mathrm{E}+04$ & $1.7 \mathrm{E}+01$ \\
\hline \multicolumn{9}{|c|}{$\begin{array}{l}\text { (a) Abbreviations are LIV: Long Irradiation Vehicle (10,000 cc total target volume per assembly); LIV-H: Hydrided LIV; R3: } \\
\text { Rapid Radioisotope Retrieval System ( } 24 \mathrm{cc} \text { target volume); R3-H: Hydrided R3; Gas Line: Target volume is } 5000 \mathrm{cc} \text {. } \\
\text { (b) Product yields are given per assembly per operating cycle. Target masses per assembly are based on available target volume, } \\
\text { allowing for volume fraction occupied by yttrium hydride pins, and on expected availability of target isotopes at high } \\
\text { enrichment. }\end{array}$} \\
\hline
\end{tabular}


From the information presented in Table 4, it is clear that FFTF can supply all, or a large fraction of, the projected U.S. requirement for these 17 therapeutic isotopes in the year 2005. This conclusion is based on the favorable comparison shown in Table 4 between the projected market demand and the production capacity of FFTF. Even for those isotope products that will require more than one core assembly to meet the production demand, a sufficient number of R3 and LIV target assemblies can be deployed to increase the FFTF's production capacity up to a level that meets the projected demand.

A comparison has also been made of the isotope production capacity of FFTF relative to the High Flux Isotope Reactor (HFIR) at the Oak Ridge National Laboratory, which is currently a major source of medical isotopes produced under the DOE/NE-70 program. This comparison was made on the basis of two key factors: (1) the curies of a product isotope that can be produced per gram of target material in a typical irradiation cycle, and (2) the target volume available in the reactor's core region. These factors

Table 5. Comparison of Medical Isotope Production by FFTF and HFIR ${ }^{(a)}$

\begin{tabular}{|c|c|c|c|c|c|c|c|c|}
\hline \multirow[b]{2}{*}{ Isotope } & \multirow[b]{2}{*}{$\begin{array}{c}\text { Target } \\
\text { Material } \\
\end{array}$} & \multicolumn{2}{|c|}{ Ci Product/g Target ${ }^{(b)}$} & \multirow{2}{*}{$\begin{array}{c}\begin{array}{c}\text { Production } \\
\text { Ratio }\end{array} \\
\text { (FFTF/HFIR) } \\
\end{array}$} & \multicolumn{2}{|c|}{$\begin{array}{c}\text { Target } \\
\text { Volume } \\
\text { (e) }\left(\mathrm{cm}^{3}\right)\end{array}$} & \multirow{2}{*}{$\begin{array}{l}\text { Volume Ratio } \\
\text { (FFTF/HFIR) }\end{array}$} & \multirow{2}{*}{$\begin{array}{c}\text { FFTF } \\
\text { Advantage } \\
\text { (Prod. Ratio } \\
\text { x Vol. Ratio) } \\
\end{array}$} \\
\hline & & FFTF & HFIR & & FFTF & HFIR & & \\
\hline Ac-227 & $\mathrm{Ra}-226$ & $2.53 E+00$ & $1.52 E+00$ & 1.7 & 38500 & 464 & 83.0 & 140 \\
\hline Cd-109. & Cd-108 & $6.19 E+00$ & $5.34 \mathrm{E}+00$ & 1.2 & 77100 & 464 & 166.2 & 190 \\
\hline $\mathrm{Cu}-64$ & $\mathrm{Zn}-64$ & $1.56 \mathrm{E}+00$ & $1.18 E+00$ & 1.3 & 72 & 12.9 & 5.6 & 9.5 \\
\hline $\mathrm{Cu}-67$ & $\mathrm{Zn}-67$ & $6.79 E-02$ & 4.90E-02 & 1.4 & 72 & 12.9 & 5.6 & 7.8 \\
\hline Ho-166 & Ho- 165 & $1.59 \mathrm{E}+03$ & $1.25 E+03$ & 1.3 & 72 & 12.9 & 5.6 & 7.3 \\
\hline $\mathrm{I}-131$ & Te-130 & $6.61 \mathrm{E}+00$ & $3.59 \mathrm{E}+01$ & 0.2 & 72 & 12.9 & 5.6 & 1.1 \\
\hline Ir-192 & Ir-191 & $1.26 E+02$ & $5.23 E+01$ & 2.4 & 77100 & 464 & 166.2 & 400 \\
\hline Mo-99 & Mo-98 & $7.88 E+01$ & $2.74 E+01$ & 2.9 & 72 & 12.9 & 5.6 & 16.2 \\
\hline Os-194 & Os-192 & $6.80 E+00$ & $8.00 E+00$ & 0.9 & 77100 & 464 & 166.2 & 140 \\
\hline P-32 & S-32 & $5.90 E+00$ & $4.28 E+00$ & 1.4 & 72 & 12.9 & 5.6 & 7.8 \\
\hline P-33 & S-33 & $1.84 E+01$ & $4.93 E+01$ & 0.4 & 77100 & 464 & 166.2 & 62 \\
\hline Pd-103 & Pd-102 & $1.12 E+02$ & $2.95 \mathrm{E}+02$ & 0.4 & 72 & 12.9 & 5.6 & 2.2 \\
\hline Pt-195m & Pt-195 & $5.77 \mathrm{E}+00$ & $4.08 \mathrm{E}+00$ & 1.4 & 72 & 12.9 & 5.6 & 7.8 \\
\hline $\operatorname{Re}-186$ & $\operatorname{Re}-185$ & $3.51 E+03$ & $7.83 E+03$ & 0.4 & 72 & 12.9 & 5.6 & 2.2 \\
\hline Sc-47 & Ti-47 & $1.66 E+00$ & $1.09 E+00$ & 1.5 & 72 & 12.9 & 5.6 & 8.4 \\
\hline Se-75 & Se-74 & $1.43 E+03$ & $6.08 E+03$ & 0.2 & 38500 & 464 & 83.0 & 20 \\
\hline Sm-145 & Sm-144 & $2.00 \mathrm{E}+01$ & $1.00 \mathrm{E}+01$ & 2.0 & 38500 & 464 & 83.0 & 170 \\
\hline Sm-153 & Sm-152 & $7.33 E+03$ & $1.91 E+03$ & 3.8 & 72 & 12.9 & 5.6 & 21 \\
\hline Sr-89 & Sr-88 & 6.34E-01 & $1.76 E+00$ & 0.4 & 38500 & 464 & 83.0 & 30 \\
\hline $\mathrm{Th}-228$ & $\mathrm{Ra}-226$ & $1.30 E+02$ & $9.11 E+01$ & 1.4 & 38500 & 464 & 83.0 & 120 \\
\hline Th-229 & Ra-226 & 3.70E-02 & $2.00 \mathrm{E}-02$ & 1.9 & 38500 & 464 & 83.0 & 150 \\
\hline W-188 & W-186 & $5.95 E+00$ & $4.99 E+01$ & 0.1 & 38500 & 464 & 83.0 & 9.9 \\
\hline Xe-127 & $\mathrm{Xe}-126$ & $2.95 E+02$ & $6.88 E+02$ & 0.4 & 77100 & 464 & 166.2 & 71 \\
\hline \multicolumn{9}{|c|}{$\begin{array}{l}\text { (a) HFIR is the High Flux Isotope Reactor located at the Oak Ridge National Laboratory in Oak Ridge, Tennessee. } \\
\text { (b) For consistency with data available for HFIR, the isotope production calculations shown in this table are based on peak } \\
\text { fluxes rather than volume-average fluxes, and do not include self-shielding corrections. In contrast, the information } \\
\text { contained in Tables } 3 \text { and } 4 \text { is based on calculations that used volume-averaged fluxes in the target assemblies and included } \\
\text { self-shielding corrections. } \\
\text { (c) Target volumes for the FFIF are based on the use of } 3 \text { R3 and } 9 \mathrm{LV} \text { assemblies for medical isotope production. }\end{array}$} \\
\hline
\end{tabular}


were calculated for isotope targets placed in the high-flux region of the HFIR reactor (the "flux trap"), and for isotope production assemblies placed in Rows 4 and 6 of the FFTF's core region. As shown by the calculations presented in Table 5 for 23 medical isotopes, the rate of production per gram of target material is similar in HFIR and FFTF for many of the product isotopes. However, the large core volume of the FFTF compared to the HFIR flux trap provides a distinct overall production advantage for FFTF over HFIR for all of the 23 isotopes that were analyzed.

\subsection{Organizational Structure of the Radioisotopes Production Program}

\subsubsection{Pacific Northwest National Laboratory's Radiochemical Processing Group}

Radiochemical research and development at PNNL are conducted by members of the Radiochemical Processing Group (RPG), which consists of 75 technical and administrative staff located in a 144,000 $\mathrm{ft}^{2}$ Category II nuclear facility - the Radiochemical Processing Laboratory (described in Section 2.5 .1 of this report). The RPG, headed by Dr. John LaFemina, is administratively located within the Environmental Technology Division (ETD), one of the four major research divisions at PNNL. The organizational structure of the ETD and the RPG are illustrated in Figure 5.

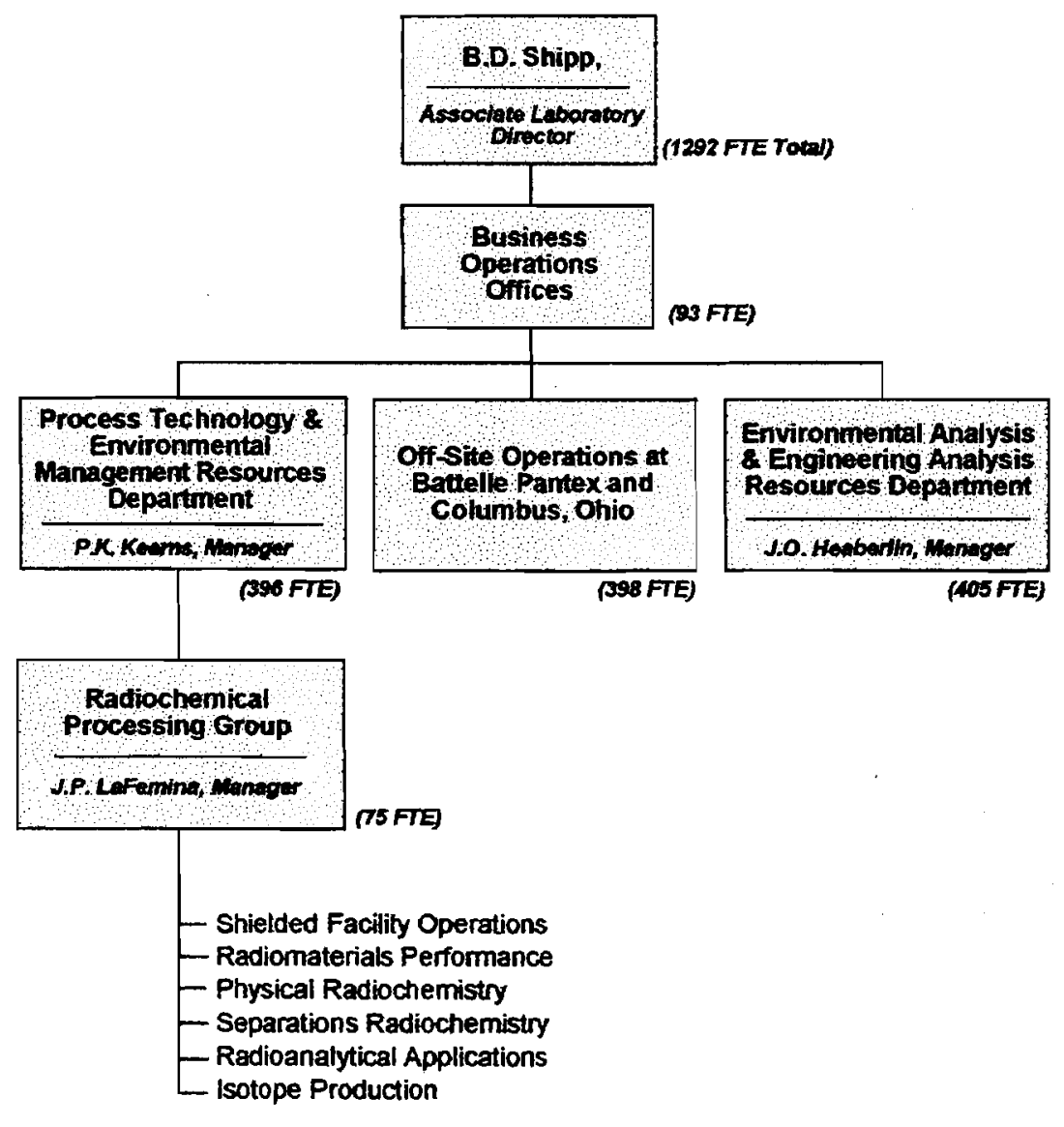

Figure 5. Organizational Chart for the PNNL Environmental Technology Division 
The primary missions of the RPG are to create and implement innovative processes for environmental cleanup and the beneficial use of radioactive materials. Primary areas of research include (1) the development of technologies for the cleanup of hazardous radiological wastes, (2) the processing and disposal of nuclear fuels, and (3) the production of medical isotopes. The total business volume of the RPG in FY 1999 is projected to be $\$ 38 \mathrm{M}$, the majority of which is based on DOE funding from the Office of Environmental Management, Defense Programs, the Office of Civilian Radioactive Waste Management, and the Office of Nuclear Energy, Science and Technology.

The RPG's staff is divided into six teams that represent the main technical capabilities of this organizational unit: (1) shielded facility operations for work with high levels of radioactive materials, (2) radiomaterials performance, (3) physical radiochemistry, (4) separations radiochemistry, (5) radioanalytical applications, and (6) isotope production.

\subsubsection{Fast Flux Test Facility}

The current organizational structure of the FFTF is shown in Figure 6. As discussed in Section 2.1 of this report, the reactor is currently in a standby mode of operation. Approximately 250 technical and administrative staff are involved in maintaining all of the essential operating systems and support services in a functional condition, including the reactor's liquid sodium heat transport system. The operating budget for the FFTF in FY 1999 is $\$ 40$ M.

Plans are being developed for the FFTF's operational and organizational structures if DOE makes a decision to restart the reactor for a future nuclear science and irradiation services mission. For operations at a 100-MW power level, a total support staff of $410 \mathrm{FTE}$ is expected to be required. The annual baseline operating budget under this condition will be $\$ 55 \mathrm{M}$ during the first year of full-scale reactor operations in FY 2005.

As part of the 90-day FFTF scoping study that is currently in progress, a business model is being developed that will incorporate the organizational and fiscal requirements for support of the wide range of products and services to be offered by the reactor. An emphasis is being placed on the development of productive partnerships between the federal government and private sector organizations that will benefit from the reactor's capabilities.

\subsubsection{Isotope Program Management}

As described in Section 2.4.1, the isotopes program at PNNL is located organizationally within the RPG. The Manager of the DOE-sponsored Hanford Radioisotopes Program, Dr. Thomas Tenforde, also functions as the lead scientist for the RPG's 12-member Isotope Production Team. In that capacity he has line management responsibilities for the staff and facilities involved in the radiochemical processing of isotopes for commercial and medical applications. These staff, together with a matrixed team of nuclear physicists, engineers, radiochemists, and nuclear safety specialists from PNNL and other Hanford 


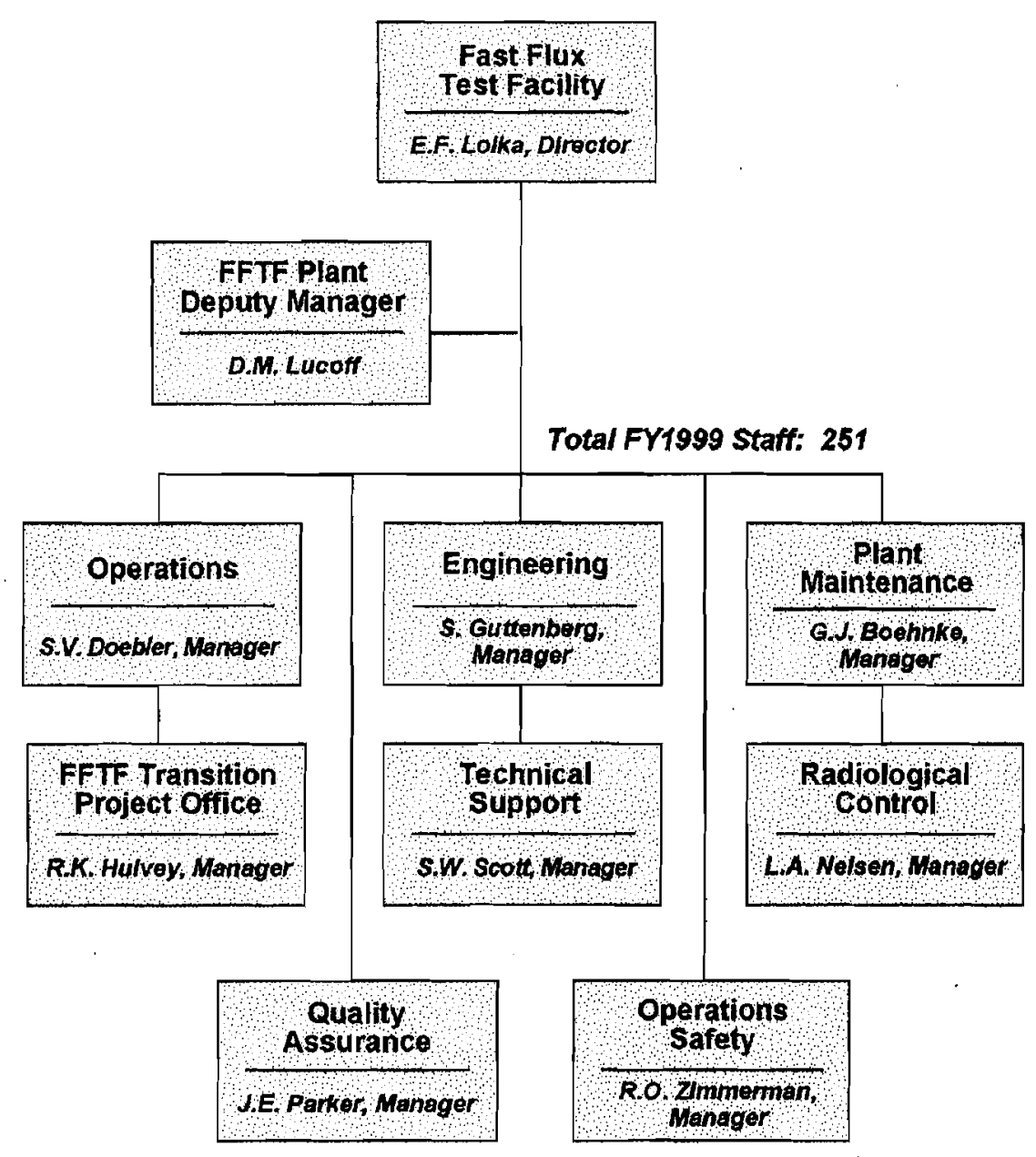

Figure 6. Organizational Chart for the Fast Flux Test Facility

contractor organizations, have functioned since 1997 as a support group for planning the proposed future FFTF isotope production mission. In all of these activities, excellent communication channels have been maintained between members of the isotopes program and key staff in the DOE Richland Operations Office.

\subsection{Isotope Production Facilities}

\subsubsection{Radiochemical Processing Laboratory}

The Radiochemical Processing Laboratory (RPL), which houses the research and development activities of the RPG (discussed in Section 2.3.1), is located in the 300 Area of the Hanford Site and is designated as Building 325. The RPL contains laboratories and specialized facilities designed for work with nonradioactive materials, microgram-to-kilogram quantities of fissionable materials, and up to megacurie quantities of other radionuclides. The RPL was built in 1953 and consists of a central area that 
contains general purpose laboratories designed for low-level radioactive work, a front wing that contains office space and shops, and two annexes that provide shielded enclosures with remote manipulators for high-level radiochemical work.

The total space within the RPL is $143,700 \mathrm{ft}^{2}$, of which $44,500 \mathrm{ft}^{2}$ is occupied by general chemistry laboratories. Figures 7 and 8 show the floor plans for the first floor and the basement of the RPL. These figures have been color-coded to show the results of a recent survey of space utilization in the RPL, which indicated that $6,950 \mathrm{ft}^{2}(15.6 \%)$ is presently unoccupied. All of the occupied, and nearly all of the unoccupied, laboratories are functional and fully equipped with standard utilities. Several of the laboratories, especially those used for radioanalytical work, have been renovated during the past few years. The upgrading and modernization of equipment within the chemistry laboratories has been given a high priority during the past two years.

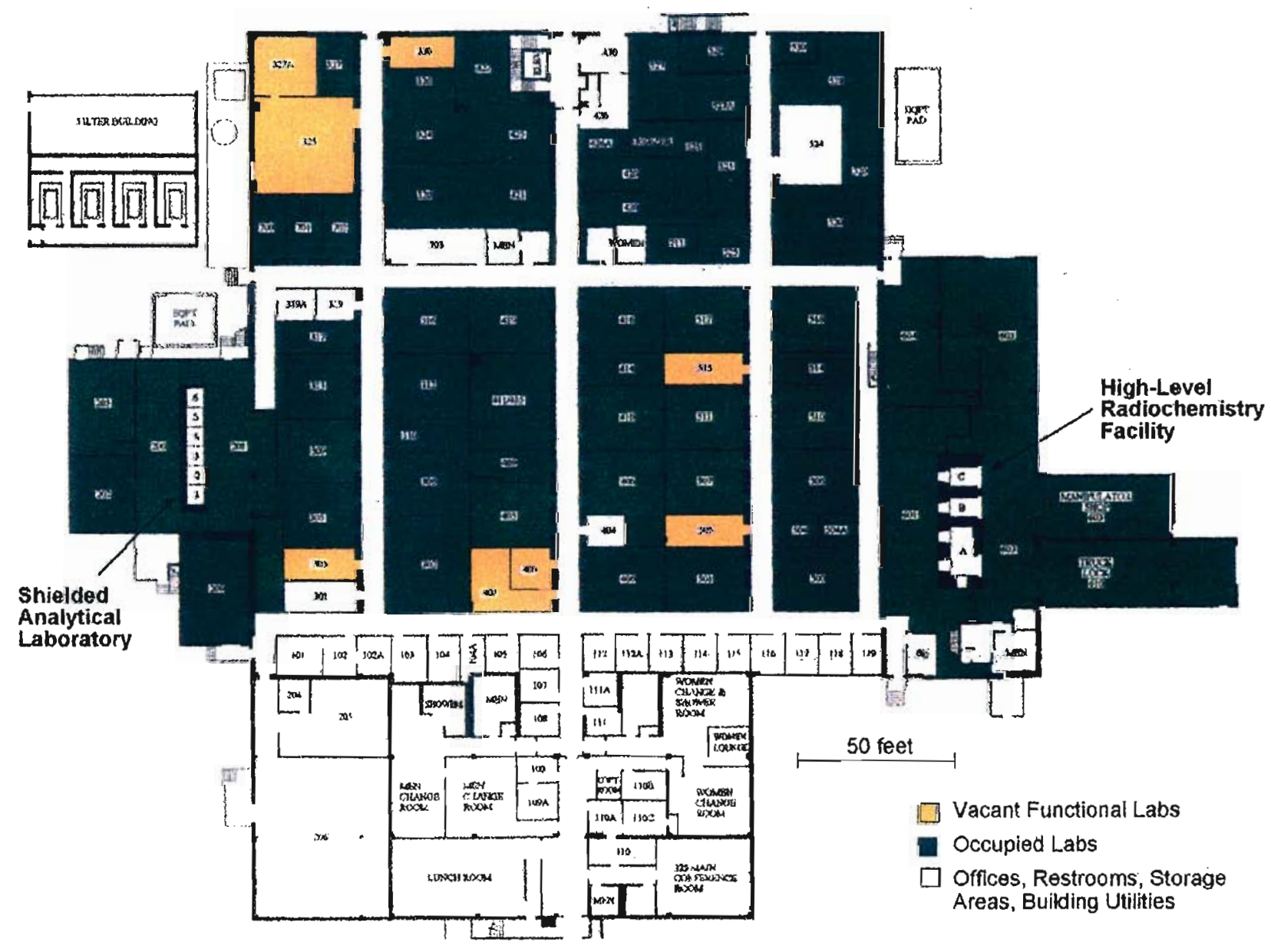

Figure 7. Map of the First Floor of the Radiochemical Processing Laboratory, Showing Occupied and Vacant Chemistry Laboratories 
During the space utilization survey at the RPL, an assessment was made of the number of fume hoods and shielded glove boxes (including several small hot cells) that are available in the chemistry laboratories for additional programmatic work. Of the 79 functional fume hoods and 23 shielded glove boxes, 50 and 15, respectively, are available for additional work.

A special feature of the RPL is the existence of two heavily shielded facilities located in annexes on the East and West sides of the building (see Figure 7). These shielded facilities are the High-Level Radiochemistry Facility (HLRF) and the Shielded Analytical Laboratory (SAL). These two hot cell complexes, which are heavily utilized at the present time, provide capabilities for conducting bench-scale to pilot-scale work with a wide variety of highly radioactive materials. Capabilities include those required to conduct radiochemical separation and purification procedures, irradiated fuel or target

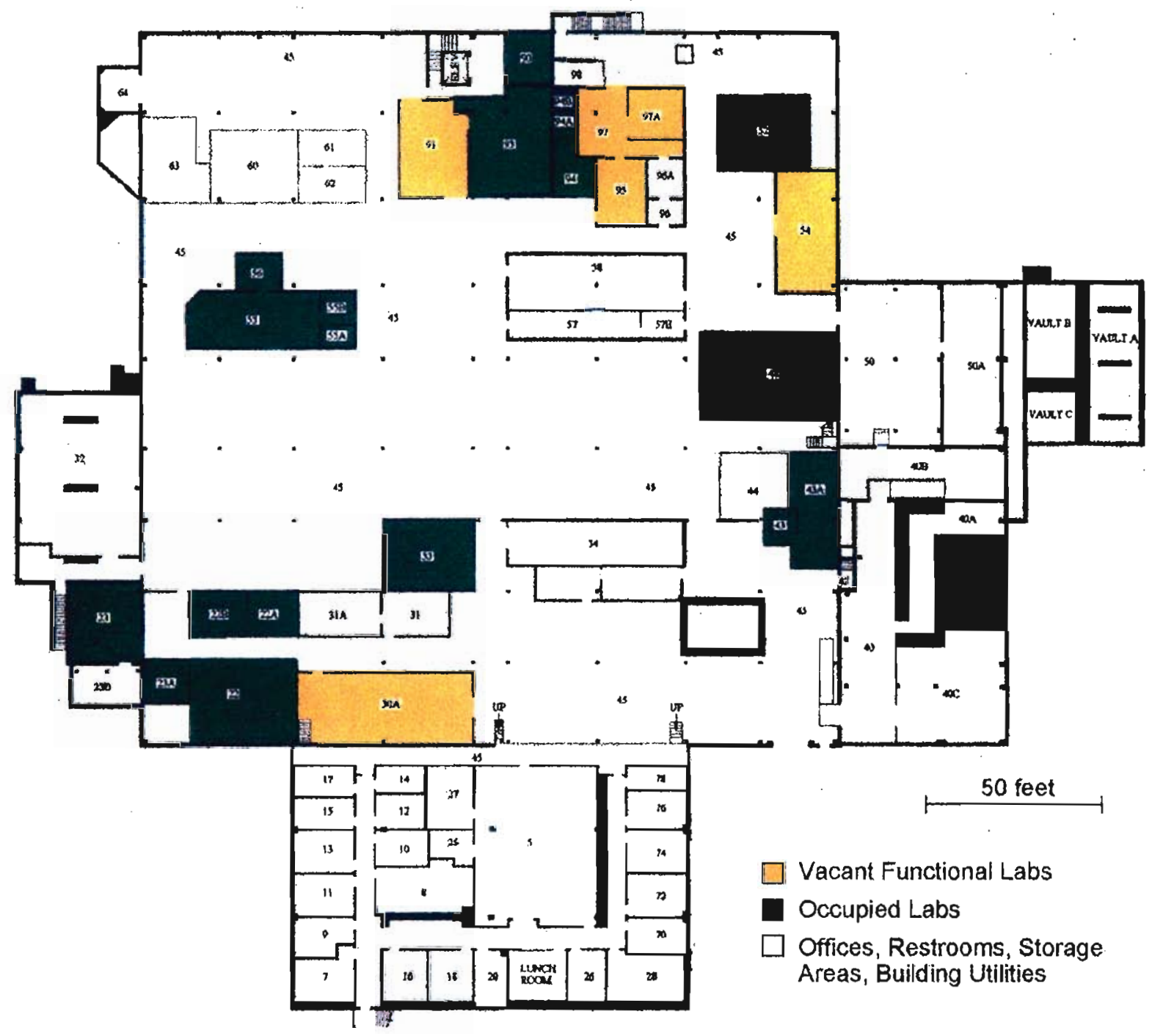

Figure 8. Map of the Basement of the Radiochemical Processing Laboratory, Showing Occupied and Vacant Chemistry Laboratories 
sectioning and processing, metallography, physical properties testing of activated metals, thermal processing (including waste vitrification), and radioanalytical and preparatory chemistry operations.

The HLRF contains three large, interconnected hot cells designated as A-Cell, B-Cell, and C-Cell. The three cells are each $15 \mathrm{ft}$ high and $7 \mathrm{ft}$ deep; the A-Cell is $15 \mathrm{ft}$ wide and the B-Cell and C-Cell are each $6 \mathrm{ft}$ wide. In-cell operations are performed using medium-duty electromechanical manipulators, with viewing of the work through leaded-glass, oil-filled windows. Closed-circuit television cameras and VCRs have been installed for detailed inspection work within the hot cells. The A-Cell and C-Cell also have overhead bridges that contain hoists with a $2200-\mathrm{kg}$ capacity. The hot cells are fully equipped with utilities, and have shielded service penetrations at the front wall for insertion of special instrumentation. Each hot cell contains several process vessels, which are located below the work deck and range in capacity from 4 to 320 liters. Access to each hot cell in the HLRF is provided by a large shielded door and a shielded double-door transfer port located in the rear wall of the cell. Cask payloads weighing up to $2200 \mathrm{~kg}$ can be transferred into and out of the hot cells using a bridge crane located in the canyon behind the cells.

The SAL contains six interconnecting hot cells, each of which is $5.5 \mathrm{ft}$ wide, $5.5 \mathrm{ft}$ deep, and $9.5 \mathrm{ft}$ high. Each hot cell is equipped with a pair of medium-duty manipulators. Turntables built into the rear walls of the hot cells provide rapid transfers of radioactive samples into and out of the cells. The SAL hot cells are equipped to perform a wide variety of analytical chemistry operations with highly radioactive samples.

As part of the planning activities for a future radioisotope production mission at FFTF, an engineering assessment was made of the capabilities of the RPL to support the radiochemical processing requirements for a wide variety of irradiated target materials. Figures 9 and 10 illustrate a preliminary design of the RPL facilities modifications that could be made to accommodate the preparation and processing of targets and isotope products following irradiation at FFTF and transport in shielded casks to the RPL. Transport would take place over a distance of $\sim 10$ miles on a four-lane highway within the Hanford Site.

The general features and functions of the RPL laboratories that would be used for processing targets irradiated at FFTF have been described in a PNNL report. ${ }^{7}$ In brief, some of the primary features of the these laboratories would be as follows:

1. A cluster of 10 laboratories would be available on the first floor of the RPL; each laboratory would contain a small hot cell, a shielded glove box, and a fume hood with interconnecting transfer ports.

2. A transfer port for receipt of casks containing irradiated targets into the A-Cell of the HLRF would be installed, and provision would be made in the $\mathrm{C}$-cell for initial processing of highly radioactive targets (e.g., irradiated europium targets containing gadolinium-153 product).

\footnotetext{
7 "Medical Isotope Production at the Fast Flux Test Facility: A Technical and Economic Assessment."
} Pacific Northwest National Laboratory Rep. No. PNNL-SA-29592, Richland, Washington (1997). 


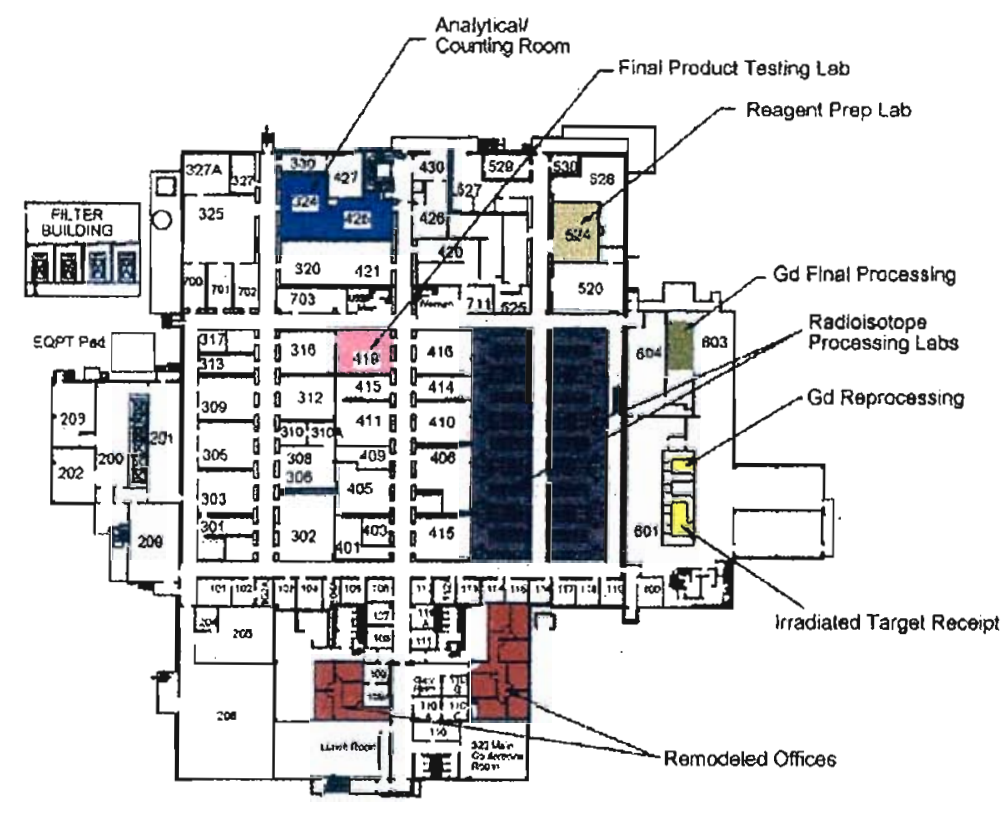

Figure 9. Proposed Locations on the First Floor of the Radiochemical Processing Laboratory for Hot Cell Operations and Radiochemical and Radioanalytical Laboratories to $\mathrm{Be}$ Used for FFTF Target Processing

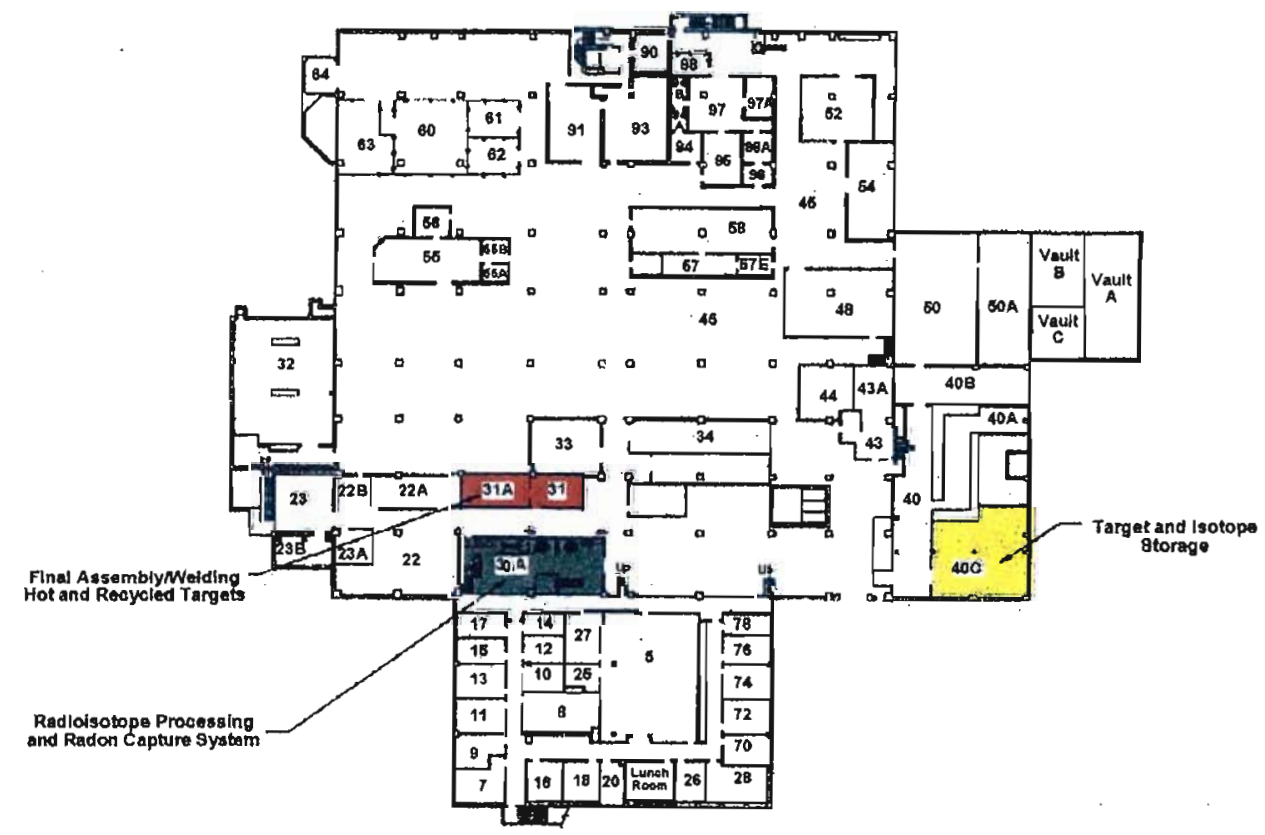

Figure 10. Proposed Locations in the Basement of the Radiochemical Processing Laboratory for Assembly, Processing, and Storage of FFTF Targets; Also Shown is the Laboratory with a Radon Gas Capture System That Will Be Used for Processing Radium-226 Targets 
3. Target preparation and storage areas would be provided in the basement of the RPL, in close proximity to facilities for the assembly and welding of radioactive and recycled targets.

4. A $1500-\mathrm{ft}^{2}$ laboratory equipped with a radon gas capture system would be available in the RPL basement for the processing of radium-226 targets and the product isotopes generated by irradiation of these targets at FFTF (all of which generate radon gas as intermediate products in their decay chains).

\subsubsection{FFTF}

The FFTF consists of the reactor and several support buildings and equipment arranged around the central reactor containment building, as shown in Figures 11 and 12. The reactor is located in a shielded cell at the center of the containment building. Heat is removed from the reactor by liquid sodium that is circulated through three primary loops, which include the pumps, piping, and intermediate heat exchangers. As illustrated in Figure 13, the primary loops are connected to secondary loops consisting of pumps, piping, flow meters, and heat exchangers. At full-power operation, the reactor inlet temperature of the sodium is $360{ }^{\circ} \mathrm{C}$ and the outlet temperature is $527^{\circ} \mathrm{C}$. During a total loss of power, the FFTF is designed to shut down automatically and the reactor will continue to be cooled by natural circulation of the sodium. An emergency power source consisting of batteries will provide essential plant monitoring capabilities in the event of a shut down. The reactor also has safety features that can maintain cooling if a leak occurs in the liquid sodium heat transport system. These safety features involve the use of elevated piping and guard vessels around all of the major components of the reactor core.

Figure 14 is a cutaway view of the reactor containment building, showing the locations of the primary pumps and intermediate heat exchangers. Secondary sodium loops transport the reactor heat from the intermediate heat exchangers to the air-cooled tubes of the dump heat exchangers located outside of the reactor containment building.

Another major system located in the reactor containment building is the Closed Loop Ex-Vessel Handling Machine (CLEM) that is used to install fuel and target assemblies in the reactor and to remove them at the end of the irradiation cycle. Figure 15 is a photograph of the CLEM system.

After completion of an irradiation cycle, an irradiated assembly is transferred by CLEM from the reactor to the Interim Examination and Maintenance (IEM) Cell. In the IEM Cell, which is shown in Figure 16, the irradiated assembly is washed and dried to remove residual sodium prior to disassembly. Following this procedure, irradiated target pins are removed from the assembly using the IEM Cell's manipulators, and are then loaded into pin containers for removal from the IEM Cell. The pin container is then transferred to an intermediate holding cell using CLEM. A bottom-loading transfer cask, shown in Figure 14, is then used to transfer the pin container from the reactor containment building to the cask loading station in the Reactor Service Building. At the cask loading station the pin container is loaded into an appropriate transportation cask such as the $\mathrm{T} 3$ for transfer to radiochemical processing facilities at the RPL or other locations. 


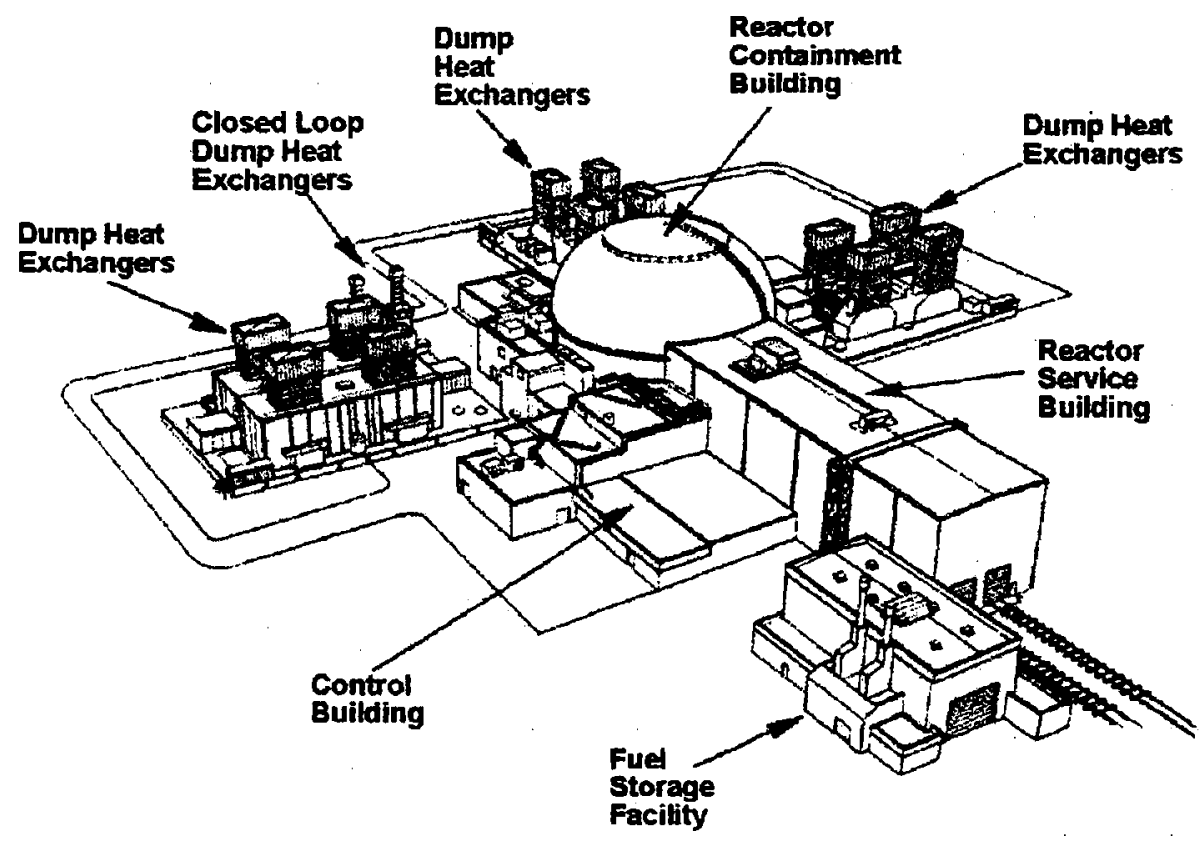

Figure 11. Fast Flux Test Facility Reactor Containment Building and External Support Facilities

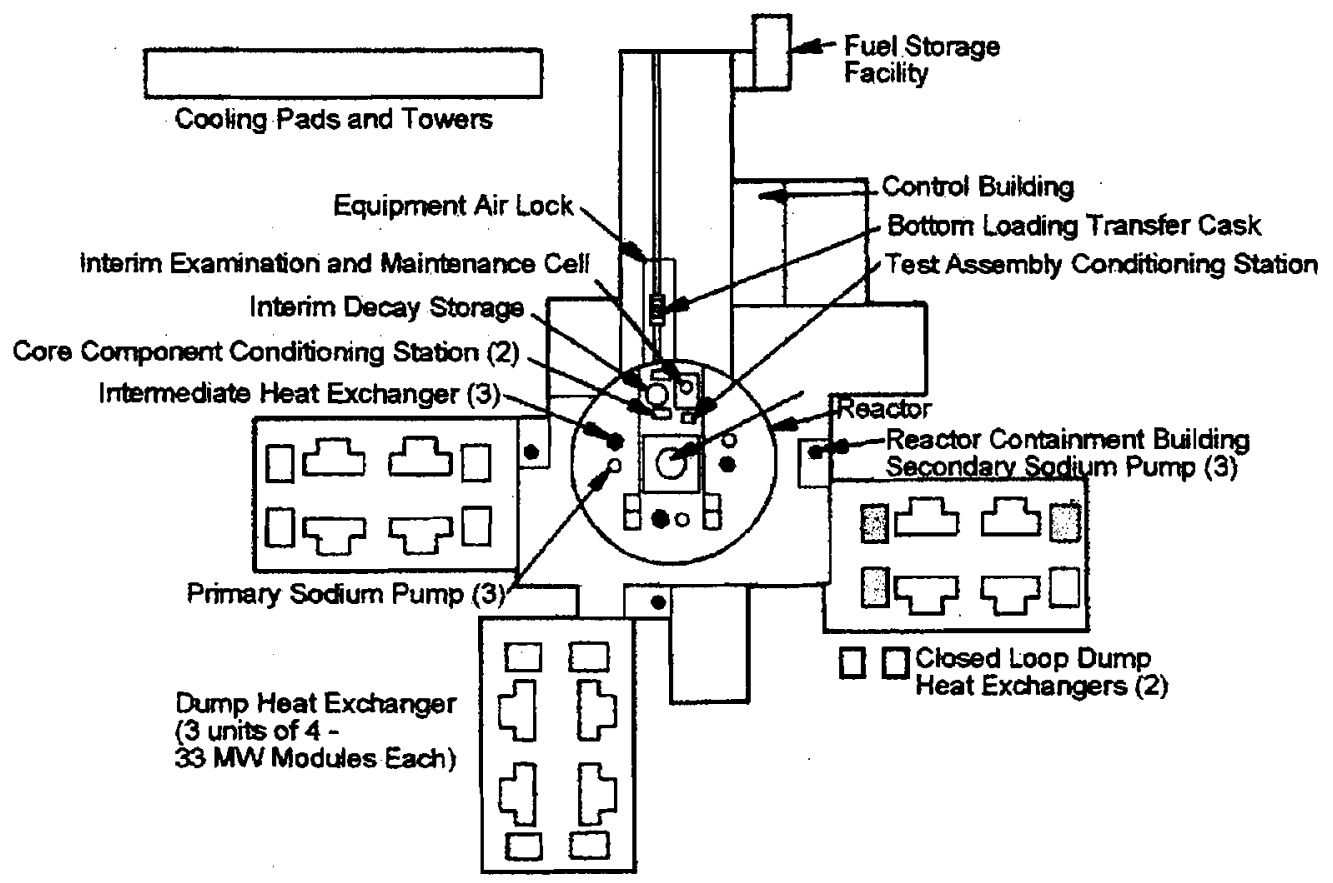

Figure 12. FFTF Plant Arrangement 


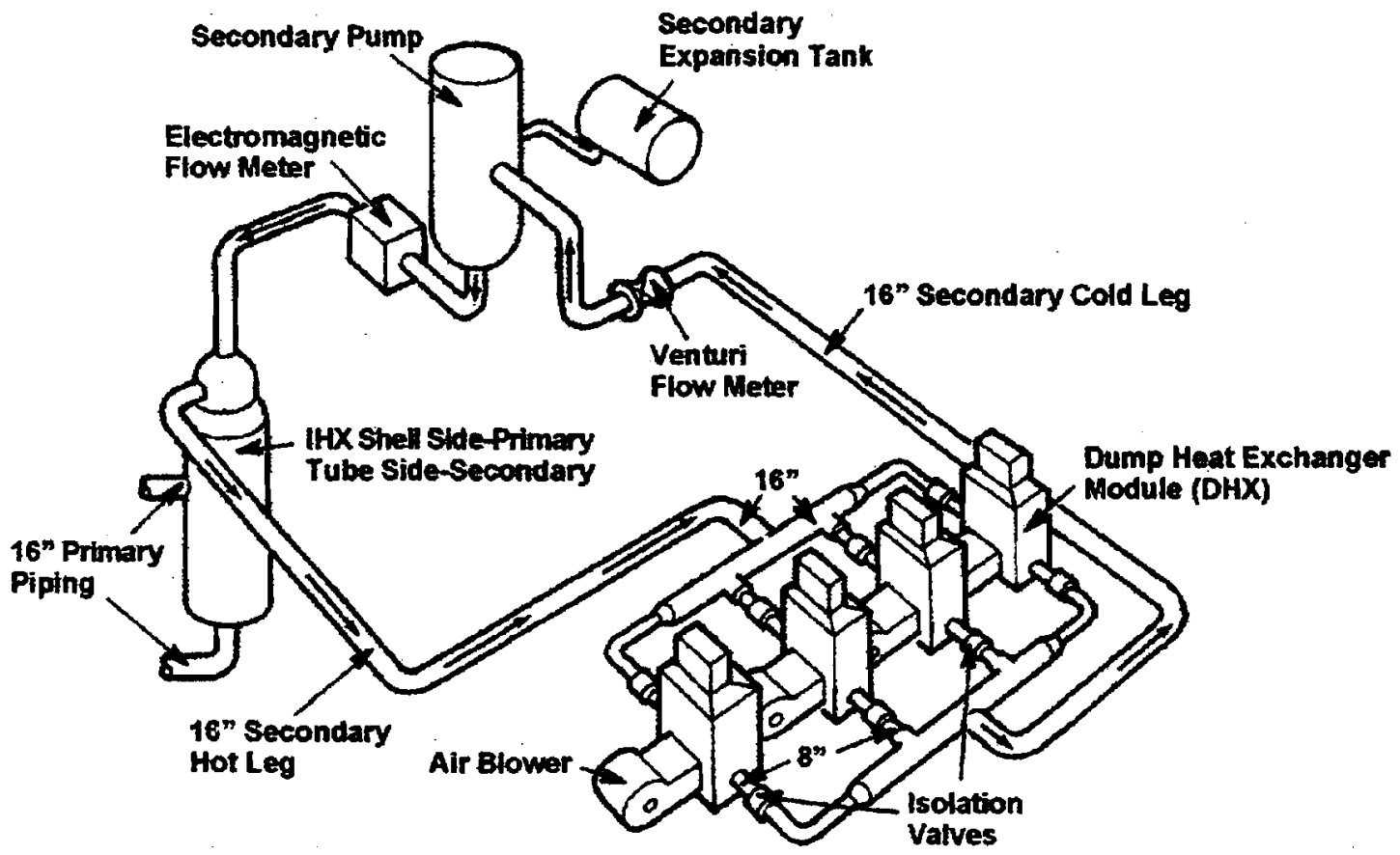

Figure 13. Schematic of FFTF Main Heat Transport System (MHTS)

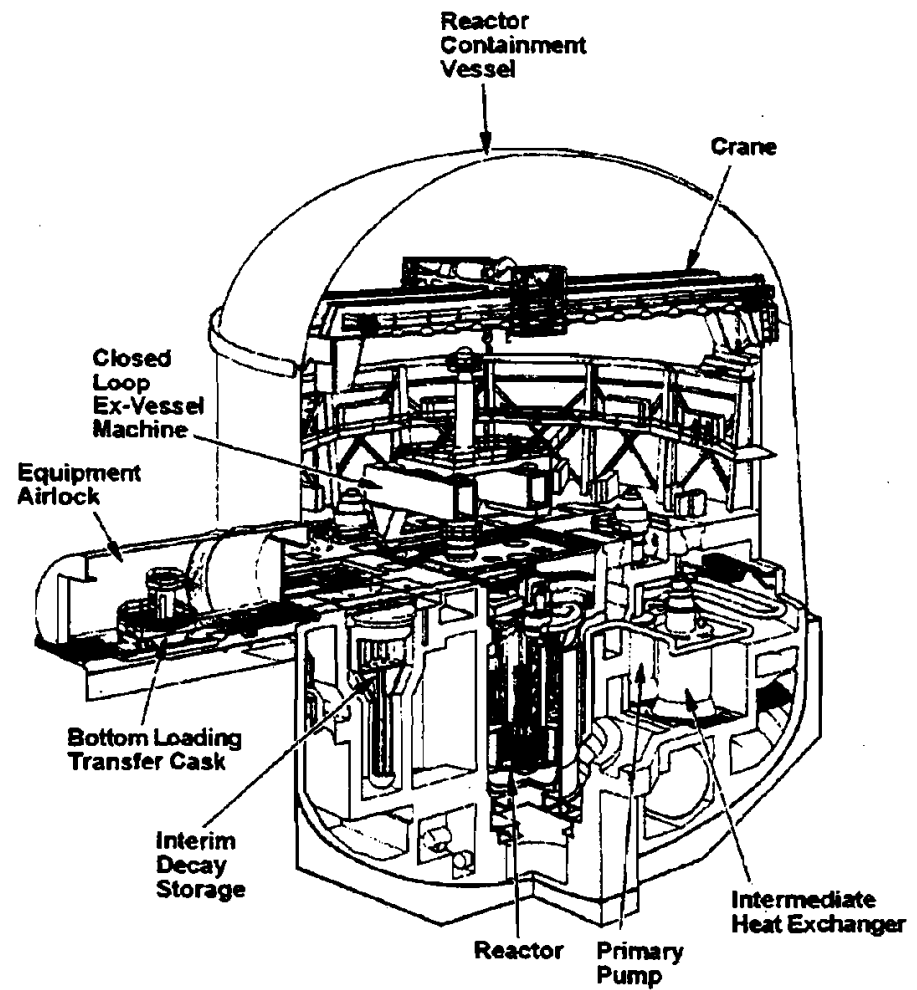

Figure 14. Cutaway View of the FFTF Reactor Containment Building 


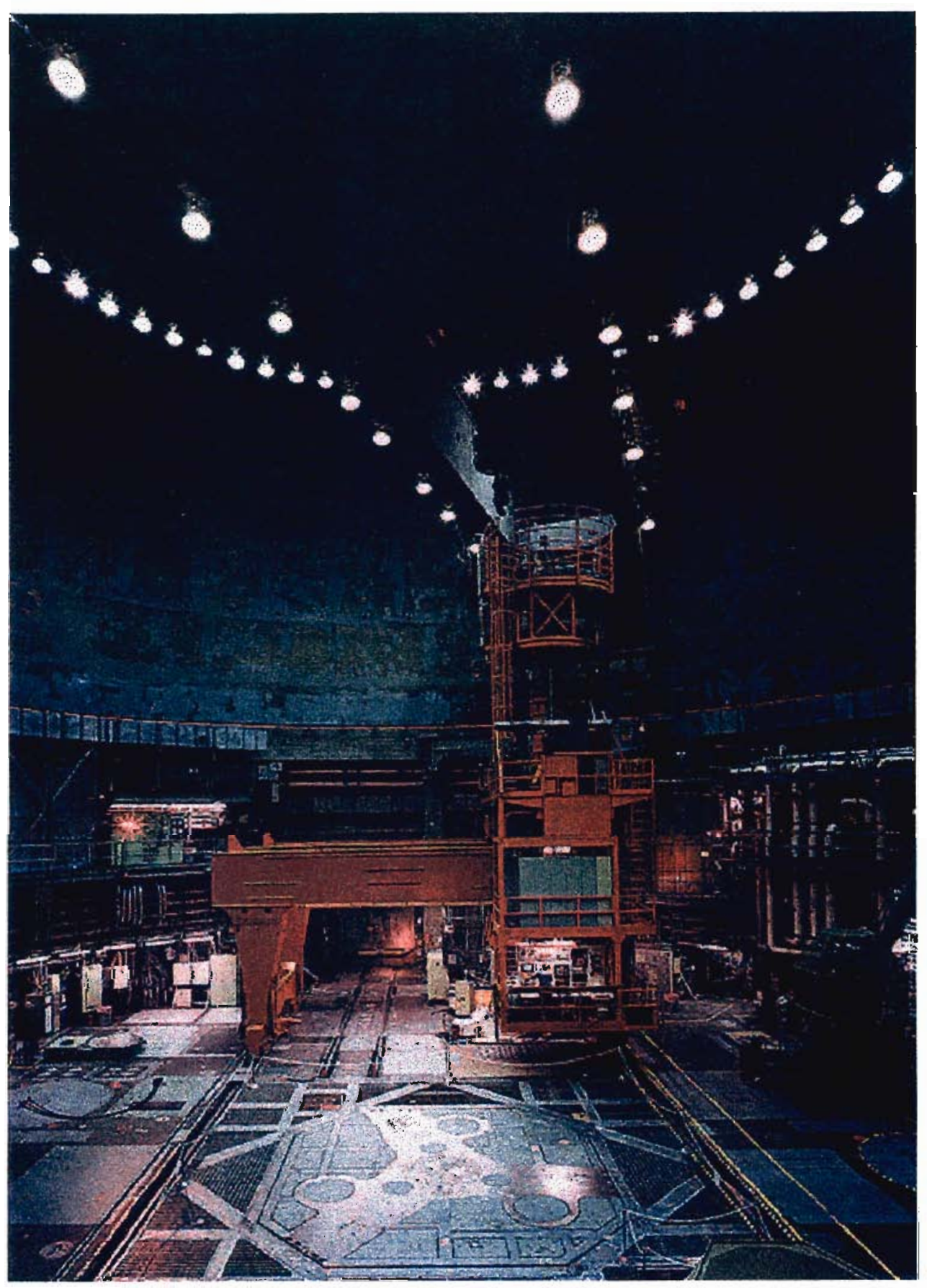

Figure 15. Closed Loop Ex-Vessel Machine (CLEM) for Installing Target Assemblies at FFTF 


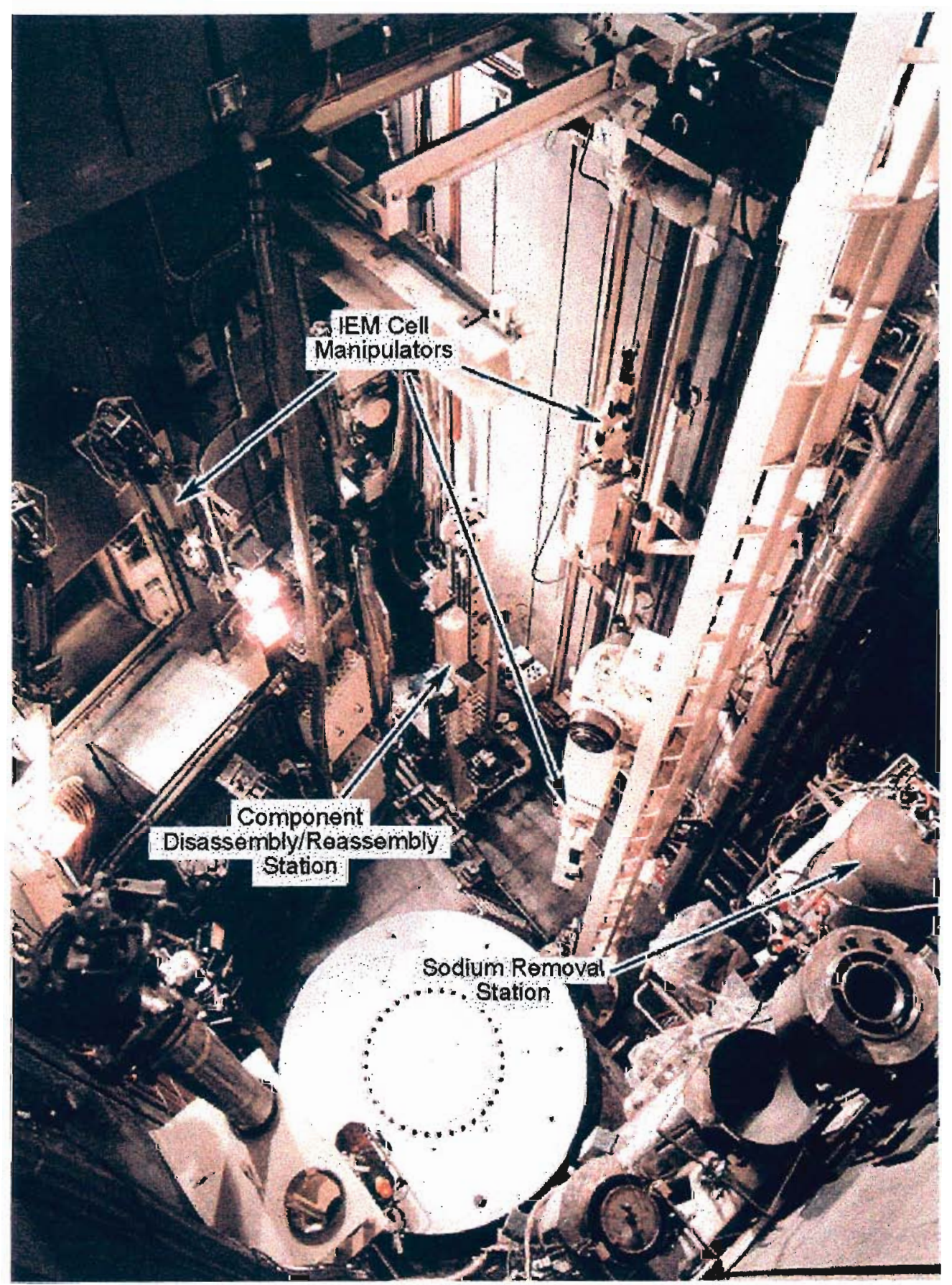

Figure 16. Interim Examination and Maintenance (IEM) Cell Used to Remove Residual Sodium from Target Assemblies and for Removal and Inspection of Target Pins 


\subsubsection{Other Facilities Relevant to the Proposed Future FFTF Isotope Production Mission}

In planning for a proposed future FFTF isotope production mission, several facilities at the Hanford Site in addition to the RPL have been examined as possible locations for the preparation of targets and the processing of isotope products. In all cases, these facilities are in good condition and have some desirable physical features and equipment that could make them advantageous as locations for the preparation and/or processing of FFTF targets. Three of these facilities are briefly described below.

Building 306E. This facility is located in the 300 Area of the Hanford Site, and has been used to fabricate a variety of reactor components, fuel assemblies, and radioisotope target assemblies in the past. Some of the equipment and Non-Destructive Examination (NDE) equipment still exist in the building. Based on a preliminary engineering evaluation, a conceptual design plan has been developed for the utilization of Building $306 \mathrm{E}$ for the fabrication of isotope targets and gas tag capsules. Figure 17 shows the first floor plan of the building and the areas that would be used to fabricate and test the target pins for LIV assemblies and the encapsulated targets for R3 assemblies. The targets would be subjected to NDE and placed in secure storage areas within Building 306E before shipment to FFTF.

Postirradiation Testing Laboratory (PTL). The PTL is located in the 300 Area at the Hanford Site and is designated as Building 327. This facility contains 13 hot cells and support laboratories for the physical and metallurgical examination of irradiated fuels, fission products, and irradiated structural materials. A floor plan of the PTL is shown in Figure 18. The central region of the building contains a $215 \mathrm{ft}$. by $32 \mathrm{ft}$. canyon area, with two overhead bridge cranes that can transport shielded containers or heavy equipment weighing up to 20 tons. This central canyon area contains 10 large hot cells and transfer storage areas. All of the hot cells are heavily shielded and fully equipped with viewing windows, manipulators, and utilities. One of the hot cells is the Special Environmental Radiometallurgy Facility (SERF), which has an inert nitrogen gas atmosphere. The basement of the PTL contains equipment storage facilities, hot cell exhaust systems, high-level liquid waste piping, and the building's power and utility services.

Decontamination of the hot cell facilities at the PTL has been underway for two years, and is expected to be completed within the next two years. Only a small amount of programmatic work is currently being conducted at the PTL, and a study on the long-range utilization of this facility is underway. One option that is being explored is the use of part or all of the PTL's facilities by commercial companies under lease agreements. This alternative may be attractive for establishing long-term business relationships with companies interested in the preparation and processing of targets irradiated at FFTF.

Maintenance and Storage Facility (MASF). The MASF is a multi-purpose service center which supports the specialized maintenance and storage requirements of the FFTF. The building is located $\sim 500 \mathrm{ft}$. north of FFTF, and is within the security perimeter of the 400 Area on the Hanford Site. The MASF provides the capability for sodium film removal, decontamination, repair, and storage of non-fuel components and hardware for the FFTF. A floor plan for the main building is shown in Figure 19. The MASF complex consists of the main building and a two-story service wing. 


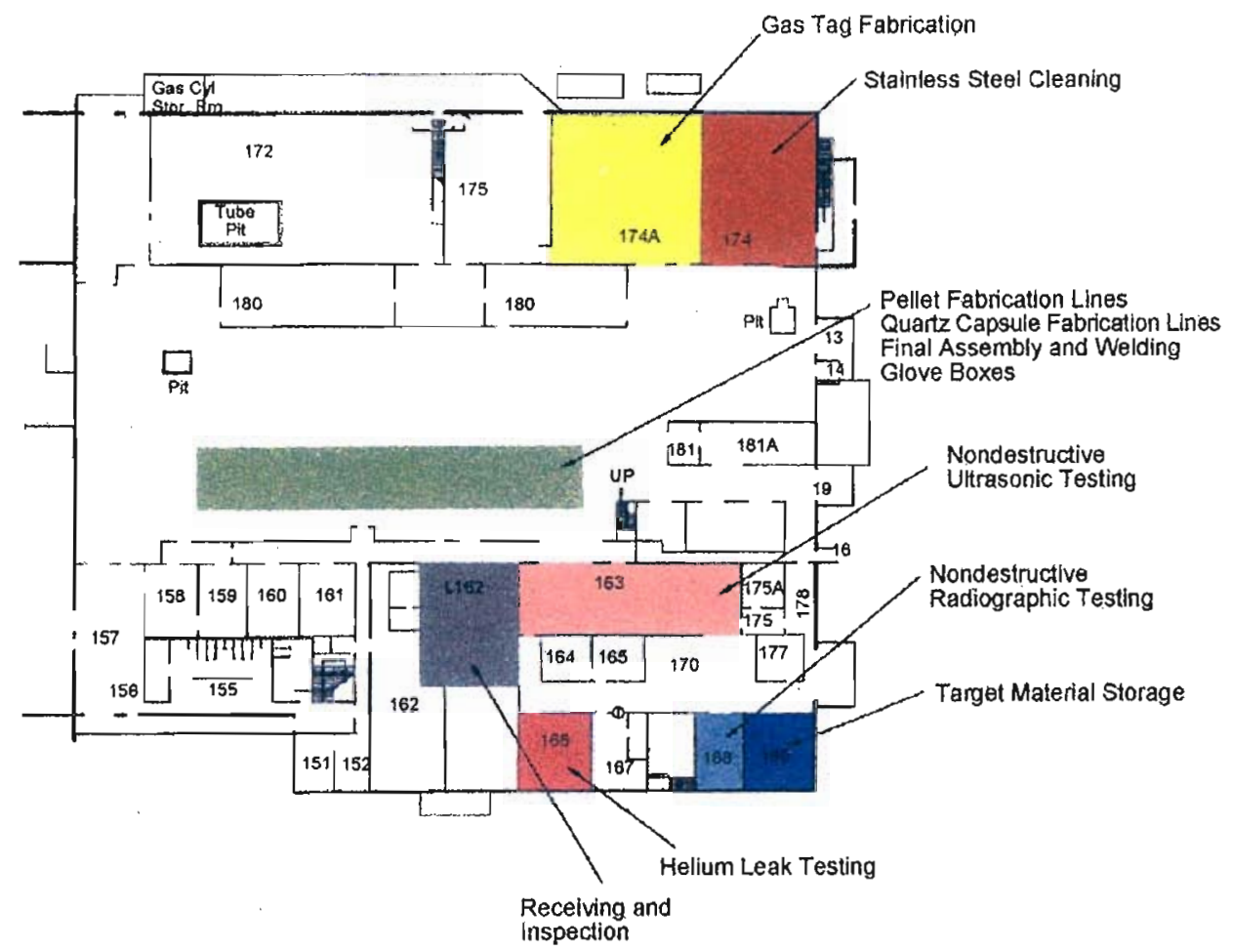

Figure 17. First Floor Plan for Building 306E, Showing Locations for FFTF Target Preparation and Nondestructive Testing

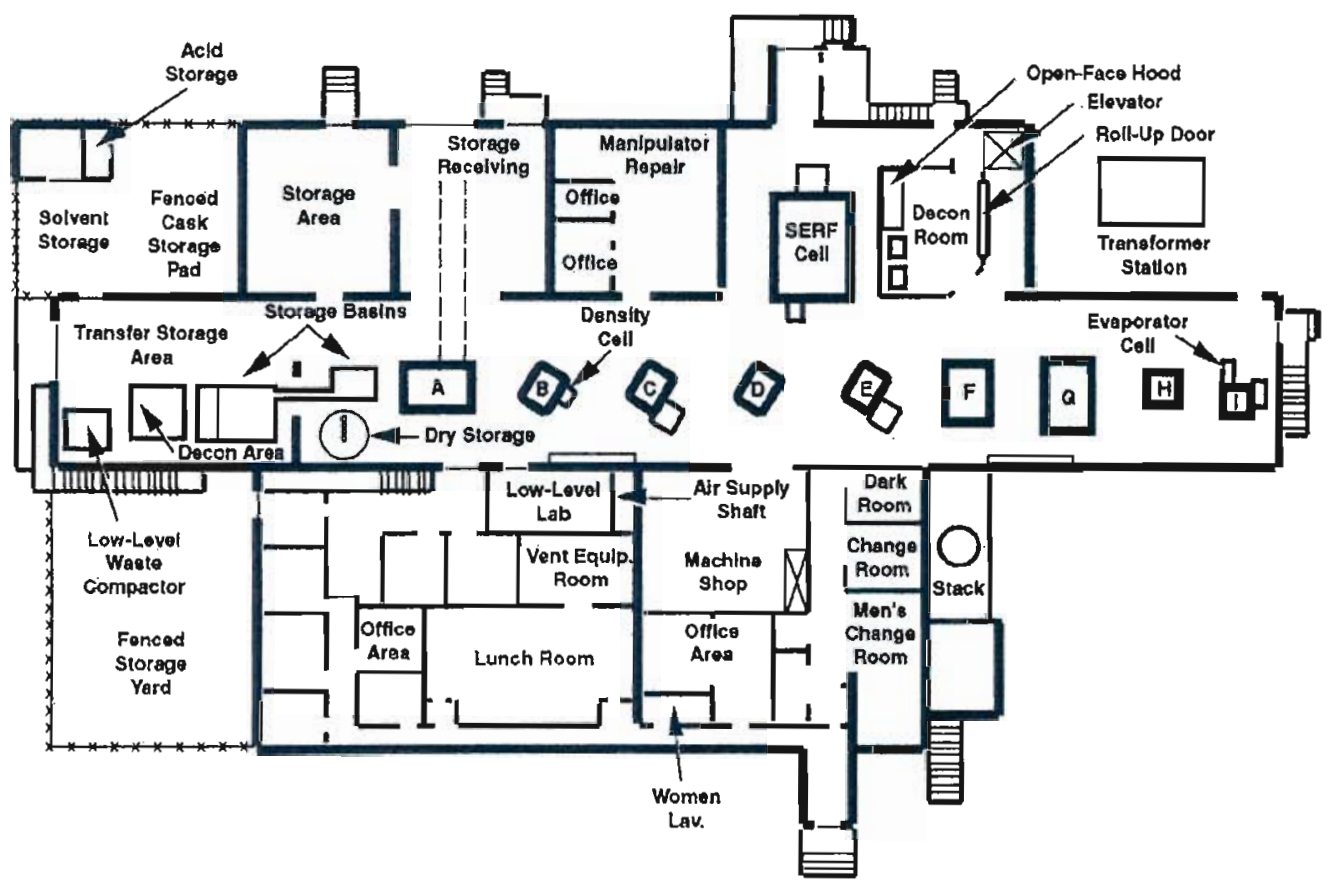

Figure 18. Floor Plan of the Postirradiation Testing Laboratory (PTL) 


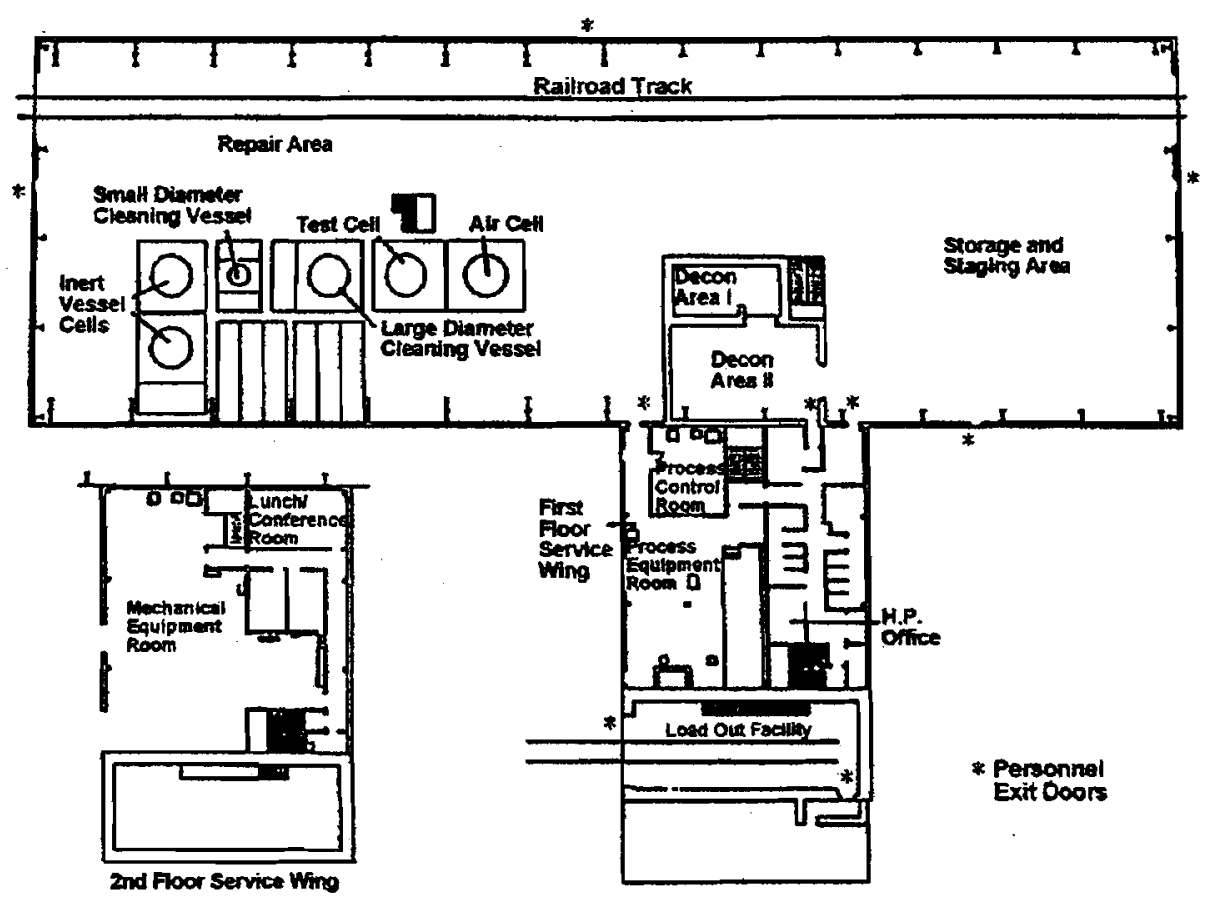

Figure 19. Floor Plan of the FFTF Maintenance and Storage Facility (MASF)

The main building of the MASF facility contains a $28,000 \mathrm{ft}^{2}$ area that is serviced by a 60 -ton overhead bridge crane and a 10-ton auxiliary hoist. One half of this area is a high-bay section that is also serviced by a 200 -ton overhead crane and a 25 -ton auxiliary hoist. This section of the building has a height of $105 \mathrm{ft}$. and contains floor space for repairs and maintenance of large equipment. It also has below-grade shielded hot cells for sodium cleaning and equipment maintenance activities. The other half of the MASF's main building is a low-bay area with a height of $49 \mathrm{ft}$. and a 10-ton overhead hoist that is used to handle equipment during transport to and from the decontamination areas in MASF.

A special feature of the MASF is a large shielded enclosure that contains two shielded decontamination rooms (denoted as Decon I and II). These areas can be used for both remote and hands-on cleaning of small equipment items and tools that are contaminated with radioactive material. The Decon I area contains viewing windows and manipulators for remote operations and has a 5-ton overhead hoist.

\subsubsection{Capital Investment Requirements}

As part of the planning activities for a future FFTF nuclear science and irradiation services mission, an estimate has been prepared of the costs associated with restarting the reactor for steady-state operations at a $100 \mathrm{MW}$ power level. This estimate, expressed in FY 1999 dollars, is $\$ 229 \mathrm{M}$. The capital expenditures are distributed over a four-year period from FY 2001 - FY 2004, and include funds for (1) recovering systems that were shut down prior to the standby decision in late 1993, (2) equipment and instrumentation upgrades, (3) fabrication of $R 3$ vehicles for retrieval of short-lived isotopes, 
(4) modification of hot cells and support laboratories for target processing operations, and (5) staff increases and training. Once restarted, the estimated annual cost of FFTF operations is $\$ 55 \mathrm{M}$. A more detailed description of the schectule and costs for FFTF restart are contained in a document submitted to DOE in March, $1999 .^{8}$

\subsection{Isotope Production Costs, Pricing, and Sales Record}

\subsubsection{Activity-Based Costing and Isotope Pricing}

Approximately four to five months prior to the beginning of a new fiscal year, the PNNL isotopes program office prepares a budgeted operations statement with supporting schedules and cost/price analyses for each isotope product and related services. This statement contains detailed estimates of labor and supply costs for each element of work involved in the production, packaging, sales and distribution of isotope products. Estimates of labor and supply costs associated with process development projects are also included in the budgeted operations statement. An activity-based costing process is used, with the elements of work defined in a four-level work breakdown structure (WBS). As an example of this process, Table 6 shows the elements of the first three WBS levels for activities described in the FY 1999 budgeted operations statement prepared by PNNL.

Following a review of the annual operations statement by staff at DOE/NE-70 and final decisions on the fiscal year budget for the isotopes program, discussions are held between DOE and the PNNL manager of the Hanford Radioisotopes Program. Based on these discussions, any necessary modifications are made in the planned activities and associated costs. Upon receipt of formal guidance from DOE on funded activities during the coming fiscal year, the PNNL manager of the Hanford Radioisotopes Program prepares a detailed Project Management Plan (PMP) for approval by the DOE Richland Operations Office. Significant deviations from schedule or cost in any element of work described in the PMP are addressed by a formal change control process involving DOE review and, if necessary, budget adjustments that are subject to approval by DOE/NE-70. Revenues from isotope sales and expenses associated with all program activities are summarized in monthly, quarterly, and annual reports submitted to DOE.

The use of activity-based costing has been very beneficial in tracking expenses associated with the production, packaging, distribution and sales of medical isotopes produced by PNNL. During the period from 1996 to 1998 in which the revenue from sales of PNNL's yttrium-90 product increased 14-fold, increases also occurred in the costs of production, packaging and distribution of this product which could be closely monitored by using the activity-based costing method. An example of the type of activity flowchart developed by PNNL is shown in Figure 20 for work related to the packaging and shipping of yttrium-90 to medical customers. Using the four-level WBS approach, costs were closely estimated for each element of work shown in the flowchart. These costs are summarized in Table 7. A flowchart and

8 "Capabilities and Economic Assessment of the Use of the Fast Flux Test Facility for Isotope Production and Research." Predecisional draft report for the DOE Office of Nuclear Energy, Science, and Technology (March 18, 1999). 
activity-based cost analysis were also prepared for the radiochemical tasks associated with extraction of yttrium-90 from strontium-90 generators and the subsequent dispensing of the yttrium-90 product into customer vials. By using this activity-based approach, it was possible to anticipate increases in the expense associated with providing ytrium-90 to medical customers as a function of the number of vials prepared and the number of packages shipped to customers on a weekly basis. Accurate projections can also be made by this method of the monthly revenue versus expense profile, as well as the "economy of scale" achieved by serving a rapidly expanding market.

Table 6. Level 3 Work Breakdown Structure Outline

\begin{tabular}{|c|c|c|c|l|c|}
\hline I & II & III & IV & \multicolumn{1}{|c}{ Definition } & B\&R $^{(\mathbf{a}}$ \\
\hline 1 & & & & Radioisotopes & ST01 \\
\hline & 4 & & & Chemical Processing & ST01 \\
\hline & & 1 & & Yttrium-90 & ST01 \\
\hline & 5 & & & Waste Mgmt & ST01 \\
\hline & & 1 & & Yttrium-90 & ST01 \\
\hline & 6 & & & Quality Assurance & ST01 \\
\hline & & 1 & & Yttrium-90 & ST01 \\
\hline & 7 & & & ES\&H Safety, Regulatory Compliance & ST01 \\
\hline & & 1 & & Yttrium-90 & ST01 \\
\hline & 8 & & & Packaging & ST01 \\
\hline & & 1 & & Yttrium-90 & ST01 \\
\hline & 9 & & & Program Management & ST01 \\
\hline & & 1 & & Yttrium-90 & ST01 \\
\hline 3 & & & & Storage \& Distribution & ST03 \\
\hline & 1 & & & Storage & ST03 \\
\hline & & 1 & & Sr-90 & ST03 \\
\hline 4 & & & & Research \& Development & ST04 \\
\hline & 1 & & & Process Development & ST04 \\
\hline & & 2 & & Purify Ac-227 \& Th-228 & ST04 \\
\hline & 2 & & & Research & ST04 \\
\hline & & 2 & & Ra-223 Immunoconjugates & ST04 \\
\hline 7 & & & & HQ Requests & ST07 \\
\hline & 1 & & & Y-90 Privatization & ST07 \\
\hline & & 1 & & Sr-90 Verification measurements & ST07 \\
\hline & & 2 & & Transition to NEN & ST07 \\
\hline 8 & & & & Customer Sales \& Services & ST08 \\
\hline & 1 & & & Order Processing & ST08 \\
\hline & 2 & & & Program Information \& Cost/Price Studies & ST08 \\
\hline 9 & & & & Travel & ST09 \\
\hline & 1 & & & Marketing & ST09 \\
\hline & 2 & & & Research \& Development & ST09 \\
\hline & 3 & & & Program Travel & ST09 \\
\hline 10 & & & & Equipment & \\
\hline$(a)$ B\&R is the DoE Budget and Reporting code. & \\
\hline & & & & \\
\hline & & & \\
\hline & & & & \\
\hline & & & \\
\hline
\end{tabular}




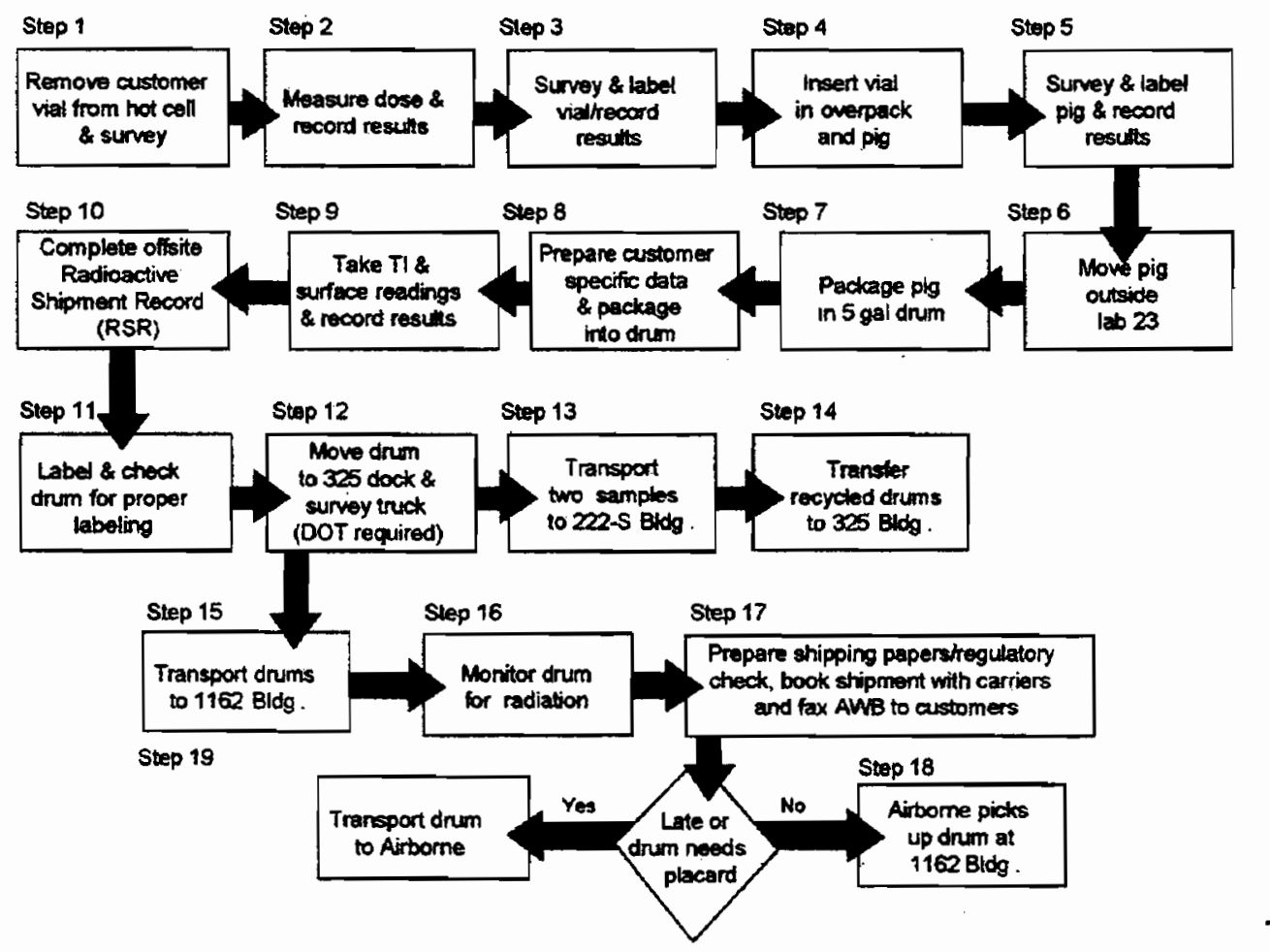

Figure 20. Flowchart Representing Procedures in the Packaging and Shipping of Vials of Yttrium-90 from PNNL to Medical Customers

Table 7. Yttrium-90 Packaging and Shipping Cost Analysis

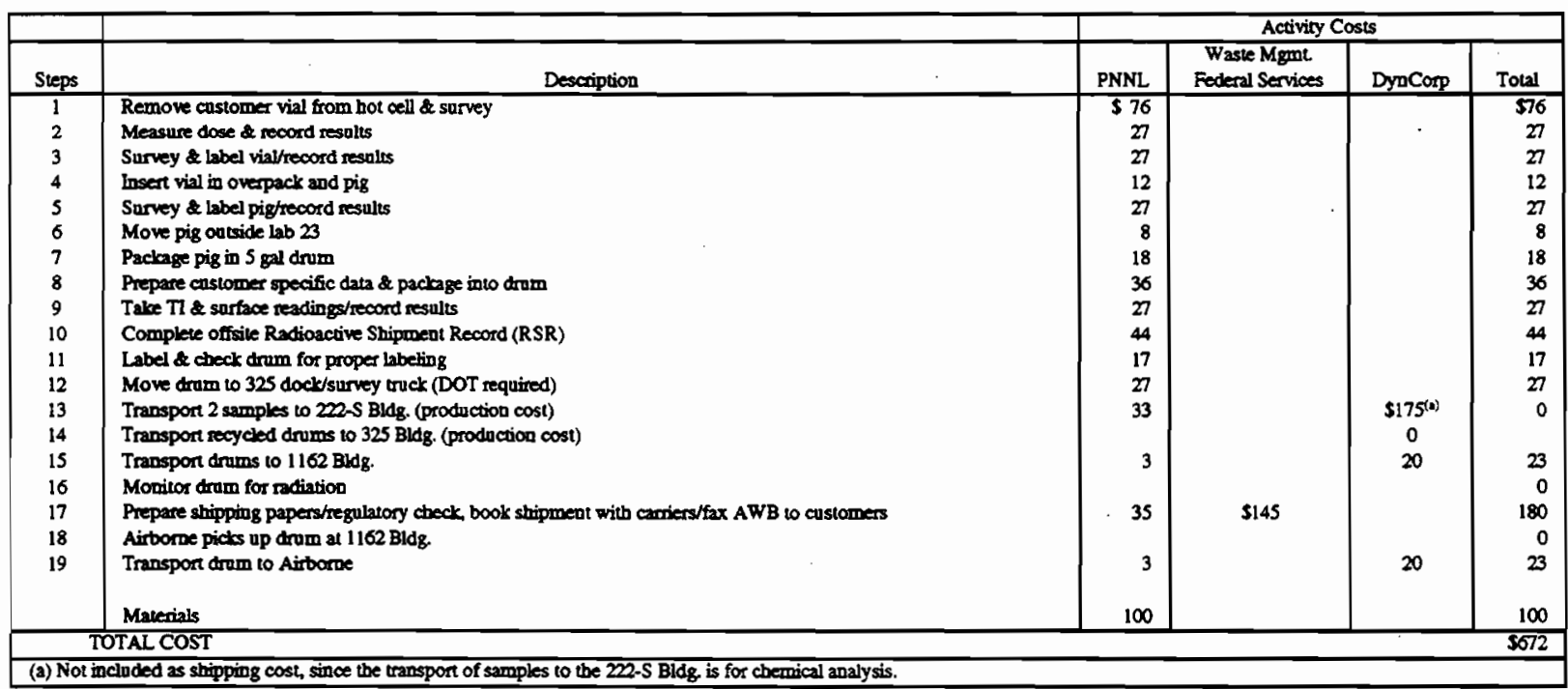


Pricing policies for all DOE isotope products are established by staff at DOE/NE-70, working in collaboration with program managers at the DOE Isotope Production Sites. An effort is made to achieve full-cost recovery for isotope products such as yttrium-90 that have a strong market position. However, for isotope products that are sold only in relatively small quantities for research applications, it is recognized that full-cost recovery is not possible and that the production of those isotopes must be subsidized by DOE. This is an appropriate role for the federal government to play, since it assures that a supply of isotopes is available for research and early-phase clinical trials at a stage when it is not economically feasible for commercial companies to provide these products.

\subsubsection{Isotope Sales and Customer Service Record}

A primary goal of staff in the Hanford Radioisotopes Program is rapid customer response and complete customer satisfaction. Although the program is relatively small, it has enhanced DOE's reputation as a reliable supplier of high-quality medical isotopes by professionally and enthusiastically serving its customers from the first phone call through the contracting, isotope production, delivery, and payment collection phases of each business transaction. Responses are also made to customer inquiries regarding isotopes that are not produced at the Hanford Site. These inquiries are answered by referring the customers to other DOE Isotope Production Sites or commercial suppliers. Our dedication to customer satisfaction is illustrated in Table 8 , which shows that a $100 \%$ on-time record has been achieved for more than 1200 shipments of yttrium- 90 sent by PNNL to medical customers over the past 2.5 years.

Table 8. Yttrium-90 Customer Service Record

\begin{tabular}{|l|l|l|l|}
\hline & \multicolumn{1}{|c|}{$\begin{array}{c}\text { FY } \\
\mathbf{1 9 9 7}\end{array}$} & $\begin{array}{c}\text { FY } \\
\mathbf{1 9 9 8}\end{array}$ & \begin{tabular}{c}
\multicolumn{1}{|c|}{ FY 1999 } \\
(Oct. '98 - Apr. '99)
\end{tabular} \\
\hline Number of customers & 26 & 44 & 40 \\
\hline Total number of shipments (cumulative) & 233 & 808 & 1,203 \\
\hline Number of shipments sent on time & 233 & 575 & 395 \\
& $(100 \%)$ & $(100 \%)$ & $(100 \%)$ \\
\hline Number of shipments received on time ${ }^{(6)}$ & 220 & 566 & 390 \\
& $(94 \%)$ & $(98 \%)$ & $(99 \%)$ \\
\hline \multicolumn{4}{|c|}{ (a) NEN ${ }^{1 \mathrm{M}}$ Life Science Products, Inc., began supplying PNNL's customers with } \\
yttrium-90 in May, 1999, as the final stage in commercialization of this program. \\
(b) Late arrivals were the result of poor weather conditions or other problems \\
encountered by the express mail carriers.
\end{tabular}

This dedication to customer service and satisfaction has been illustrated by comments received from many customers during the past two years. A few examples are the following:

“. . . consistently reliable yttrium" ... (Immunomedics)

“. . . very high-purity, reliable product" . . . (University of California at Davis)

“... excellent turnaround time and ease of doing business" ... (Stanford University)

“. . . superb customer service” . . . (Institut für Nuclearmedizin, Basel, Switzerland) 
“... excellent, pure product compared to competitors" ... (University of Gottingen)

"... unfailing, consistent labeling quality" ... (City of Hope Medical Center)

One comment received from Du Pont Pharmaceuticals provides perhaps the best tribute to our philosophy of $100 \%$ customer satisfaction: "Thank you for setting the standard so high!" 


\section{Appendix}

Questions Raised by NERAC Subcommittee 


\section{Appendix}

\section{Questions Raised by NERAC Subcommittee}

\begin{tabular}{|c|c|}
\hline $\begin{array}{l}\text { NERAC Question } \\
\end{array}$ & $\begin{array}{l}\text { Addressed in Section(s) } \\
\text { of This Report }\end{array}$ \\
\hline \multicolumn{2}{|c|}{$\begin{array}{l}\text { How well does the Department's existing five-site production infrastructure serve the need for commercial } \\
\text { and research isotopes? }\end{array}$} \\
\hline 1. What is the physical condition of the isotope processing facilities and equipment? & $2.5 .1,2.5 .2,2.5 .3$ \\
\hline $\begin{array}{l}\text { 2. What capital investments are needed to assure the near term operability of the } \\
\text { facilities? If additional resources are needed, are they practical, e.g., technically } \\
\text { rational, easily integrated into existing infrastructure, quickly implemented and } \\
\text { supportable? Will any portion be sustainable over time by local financial and } \\
\text { personnel resources? }\end{array}$ & 2.5 .4 \\
\hline $\begin{array}{l}\text { 3. What is the availability of the primary nuclear facility (accelerator or reactor) over } \\
\text { the next five years (e.g., HFIR outage, LANSCE program changes)? }\end{array}$ & $2.5 .1,2.5 .2,2.5 .3$ \\
\hline $\begin{array}{l}\text { 4. What understanding exists at each site about the priority of isotope production to } \\
\text { serve isotope customers? }\end{array}$ & 2.6 .2 \\
\hline $\begin{array}{l}\text { 5. How much influence does each site manager have in planning the use of multi- } \\
\text { purpose facilities? }\end{array}$ & 2.4 .3 \\
\hline 6. What cost-containment measures are being pursued? & 2.6 .1 \\
\hline 7. What "licensing" issues need to be addressed? & 2.2 .2 \\
\hline $\begin{array}{l}\text { 8. What unused or underused capacity, e.g., personnel, facilities, could be mobilized } \\
\text { to support a growth in isotope demand? }\end{array}$ & $2.5 .1,2.5 .3$ \\
\hline $\begin{array}{l}\text { 9. Summarize customer inquiries received during the past two years. What percent } \\
\text { was filled, referred to other facilities, rejected? Explain unfilled requests. }\end{array}$ & 2.6 .2 \\
\hline $\begin{array}{l}\text { 10. How does each site manager rate customer satisfaction for his site? For the } \\
\text { overall program? }\end{array}$ & 2.6 .2 \\
\hline $\begin{array}{l}\text { What should be the long-term role of Government in providing commercial and } \\
\text { research isotopes? }\end{array}$ & $1,2.6 .1$ \\
\hline
\end{tabular}

